\title{
The Trend and Status of Energy Resources and Greenhouse Gas Emissions in the Malaysia Power Generation Mix
}

\author{
Siti Norasyiqin Abdul Latif ${ }^{1}$, Meng Soon Chiong ${ }^{1, *}{ }^{\circledR}$, Srithar Rajoo ${ }^{1}$, Asako Takada ${ }^{2}$, Yoon-Young Chun ${ }^{2} \oplus$, \\ Kiyotaka Tahara ${ }^{2}$ and Yasuyuki Ikegami ${ }^{3}$ \\ 1 UTM Centre for Low Carbon Transport in Cooperation with Imperial College London, Universiti Teknologi \\ Malaysia, Johor Bahru 81310, Johor, Malaysia; norasyiqin@utm.my (S.N.A.L.); srithar@utm.my (S.R.) \\ 2 National Institute of Advanced Industrial Science and Technology, 16-1 Onogawa, Tsukuba 305-8569, Japan; \\ asako-takada@aist.go.jp (A.T.); yy.chun@aist.go.jp (Y.-Y.C.); k.tahara@aist.go.jp (K.T.) \\ 3 Institute of Ocean Energy, Saga University, 1 Honjo-machi, Saga 840-8502, Japan; ikegami@ioes.saga-u.ac.jp \\ * Correspondence: chiongms@utm.my
}

Citation: Abdul Latif, S.N.; Chiong, M.S.; Rajoo, S.; Takada, A.; Chun,

Y.-Y.; Tahara, K.; Ikegami, Y. The

Trend and Status of Energy Resources and Greenhouse Gas Emissions in the Malaysia Power Generation Mix. Energies 2021, 14, 2200. https:// doi.org/10.3390/en14082200

Academic Editor: Ricardo J. Bessa

Received: 29 March 2021

Accepted: 13 April 2021

Published: 15 April 2021

Publisher's Note: MDPI stays neutral with regard to jurisdictional claims in published maps and institutional affiliations.

Copyright: (c) 2021 by the authors. Licensee MDPI, Basel, Switzerland. This article is an open access article distributed under the terms and conditions of the Creative Commons Attribution (CC BY) license (https:/ / creativecommons.org/licenses/by/ $4.0 /)$.

\begin{abstract}
Environmental issues in energy policy, especially global warming, have received more attention lately than ever before. Excessive dependence on fossil fuels, deforestation, and land degradation are the three main factors that lead to increased carbon dioxide $\left(\mathrm{CO}_{2}\right)$ emissions. Consequently, the global average temperature has doubled compared to anticipation. Various international protocols and agendas have been established, pledged to restore the global average temperature to the 1990 level. As a result, energy policies worldwide have also undergone various transformations to align with these protocols since then. As a developing nation, Malaysian's electricity demand has continuously grown in the past two decades. To date, the electricity sector is still dominated by fossil fuels. Government incentives have been the most influential factor in the nation's energy mix trend. Several energy policies implemented throughout the past 22 years have seen the shift from natural gas to coal power in power plants, and in more recent years, renewable energy resources. Numerous studies in the past have independently outlined the status of various energy source in Malaysia. However, they all fell short in providing the greenhouse gas (GHG) emissions in the Malaysian energy sector. Notably, the question that remains to be answered is how GHG emissions have changed in response to the amendment in the energy mix; hence, the effectiveness of policy change in this aspect remains unknown. This paper analysed the past and present trend of Malaysia electricity generation mix and the resultant GHG emissions. In particular, this paper focused on investigating the variation of combined specific GHG emissions in the Malaysian electricity sector, in response to the policy change within the past 22 years. This provides the insight for Malaysian policymakers to evaluate the effectiveness of past policies in GHG emissions and the measures to be taken in future. The finding of this paper shows the attention on the nation's GHG emissions has evolved over the years, following the diversification in energy mix driven by the policy change. It was also found that, on average, it took a decade for a significant reduction in specific GHG emission to be visible since the government's energy policy implementation.
\end{abstract}

Keywords: energy mix; electricity; fossil fuel; renewable energy; greenhouse gases; specific GHG emission

\section{Introduction}

Conventional fossil fuel-based energy sources (oil, coal and natural gas) are the driving force behind economic progress. In 2012, the global primary energy consumption increased by a staggering $1.8 \%$ in a single year, due to the rapid decline of traditional energy sources and rising energy demand [1]. Future growth in the energy sector is foreseen primarily surrounding the new renewable energy. The shift towards renewable energy can help to reduce greenhouse gas (GHG) emissions by limiting extreme weather and climate impacts, at the same time ensuring a reliable, timely and cost-effective energy supply [2]. 
Most countries around the world, including Australia, China, United States, Russia, India, Indonesia, Singapore, Thailand, the Philippines and Malaysia, are still heavily relying on fossil fuel as the main source for electricity production, with more than $79 \%$ in their energy mix on average. On the other hand, countries like Brazil, Canada, Norway and Sweden have shifted to renewable energy sources in recent years for most of their electricity production [3]. Brazil, Canada and Norway are producing $62.9 \%, 59.6 \%$ and $95.7 \%$ of their electricity through hydropower, while Sweden fulfilled $40 \%$ of their electricity demand via Nuclear energy in 2017.

In the last two centuries, human activities have increased the $\mathrm{CO}_{2}$ concentration in the atmosphere from 280 to more than $380 \mathrm{ppm}$ by volume, and the rate is continuously growing. As a result, the global average temperature increase is far from under $1.5^{\circ} \mathrm{C}$ as pledged in the Paris Agreement 2016; instead, it is heading towards $3^{\circ} \mathrm{C}[4,5]$. The greenhouse effect happens when GHG, viz., $\mathrm{CO}_{2}$, chlorofluorocarbons (CFCs), methane $\left(\mathrm{CH}_{4}\right)$ and nitrous oxide $\left(\mathrm{N}_{2} \mathrm{O}\right)$ trap heat in the atmosphere [6]. Globally, the proportional content of these GHGs by volume is approximately $55 \%, 24 \%, 15 \%$ and $6 \%$, respectively [7]. Carbon dioxide is the primary GHG responsible for global warming owing to its large occupancy volume of the total emissions $[8,9]$. The use of fossil fuel can no longer regarded as environmentally sustainable unless carbon storage can be widely used [10].

In 2015, world leaders have agreed on the UN Agenda 2030 that includes 17 targets for Sustainable Development Goals (SDGs) [11,12]. The SDGs provide an opportunity to align climate action and the sustainable development objectives at the local, national and global level—at the same time, defining key sustainability science challenges in supporting policies. Sustainable supply chain management was identified as a key element in SDGs agenda, while the productivity and conservation of natural resources are also identified as the keys to waste reduction $[13,14]$. In Malaysia, the national development plan has always been closely related to the economic, social and environmental agenda. The implementation of SDGs needs to be aligned with future policies development. The novelty of the study is reflected by the comprehensive analysis of GHG emissions from the energy sector in Malaysia and to provide an insight for Malaysia policymakers to evaluate the effectiveness of past policies, and the measures to be taken in future.

By 2020, more than 70 countries, including some of the major GHG emitters, have pledged to achieve net-zero carbon emissions/carbon neutrality by 2050 or earlier [15-17]. It is only a matter of time that more developing countries, including Malaysia, will be required to comply with carbon neutrality as well. Part of the effort in achieving carbon neutrality status is to understand the nation's current carbon emission situation. This, in turn, allows for more effective policy and regulation to accelerate the progress towards net-zero carbon emissions.

The energy scenario and evolution of energy policies in Malaysia at different times in the past two decades have been investigated by numerous studies in the past [18-21]. The inherent obstacles in implementing these technologies were further discussed by Ali et al. [22] and Samsudin et al. [23] in depth. In brief, it seems that full implementation of the sustainable energy sources in Malaysia will take some considerable amount of time, as will be shown later in this paper as well. Therefore, fossil fuel is still regarded as the primary source of energy mix in Malaysia for the foreseeable future.

However, these past studies fell short in providing the GHG emissions in Malaysian energy sector. Notably, the question remains to be answered is how GHG emissions have changed in response to the amendment in energy mix. Thus, this study is set to analyse the past and present energy mix in Malaysia, and the corresponding evolution in GHG emissions. This is intended to provide an insight for policy makers to evaluate the effectiveness of past policies, and, more importantly, the measures to be taken in the future.

For this purpose, the first part of this paper will review the current energy resources in Malaysia and various studies in the past. The second part of this paper will put emphasis on the computation of $\mathrm{CO}_{2}$ and non- $\mathrm{CO}_{2}$ emissions $\left(\mathrm{CH}_{4} \& \mathrm{~N}_{2} \mathrm{O}\right)$ due to the energy resources usage in Malaysia power station. 


\section{Background Study}

The world's 7.7 billion population is currently growing at a rate of 90 million people per year. Electricity demand due to population growth has increased by $66 \%$ from 2000 to 2017 , more than any other industry. However, close to a quarter of the world's population still does not have proper access to electricity. Digitisation, electromobility and sector coupling will further drive up the global electricity demand [24]. Since 1990, the global electricity generation has doubled, reaching nearly $25,000 \mathrm{TWh}$ in 2016. The largest absolute growth was found from coal generation $(\sim 5300$ TWh or $+116 \%)$ and natural gas ( $\sim 3500$ TWh or $+213 \%)$. That being said, the fastest growth was in renewable energies, i.e., solar, wind and other renewable sources ( 1370 TWh or $+2224 \%)$.

By 2016, more than $75 \%$ of global electricity was still generated from non-renewable sources, primarily non-renewable thermal $(16,186 \mathrm{TWh}$ or $65 \%)$ and nuclear sources (2608 TWh or $10 \%$ ). However, this went through an unprecedented change in recent years. The booming renewable electricity accounted for more than half of global electricity capacity expansion since 2010 [3].

The world is emitting around 50 billion tonnes of GHG emissions each year. Approximately three quarters of the global $\mathrm{CO}_{2}$ emissions are generated from energy sector, as shown in Figure 1. Nearly $40 \%$ of it is due to the combustion of fossil fuel for electricity generation for the residential, commercial and industrial demand. The transportation sector, including road transportation, aviation, shipping, rail and pipeline for fuels and commodities, made up another $16 \%$ of the total $\mathrm{CO}_{2}$ emissions worldwide [25].

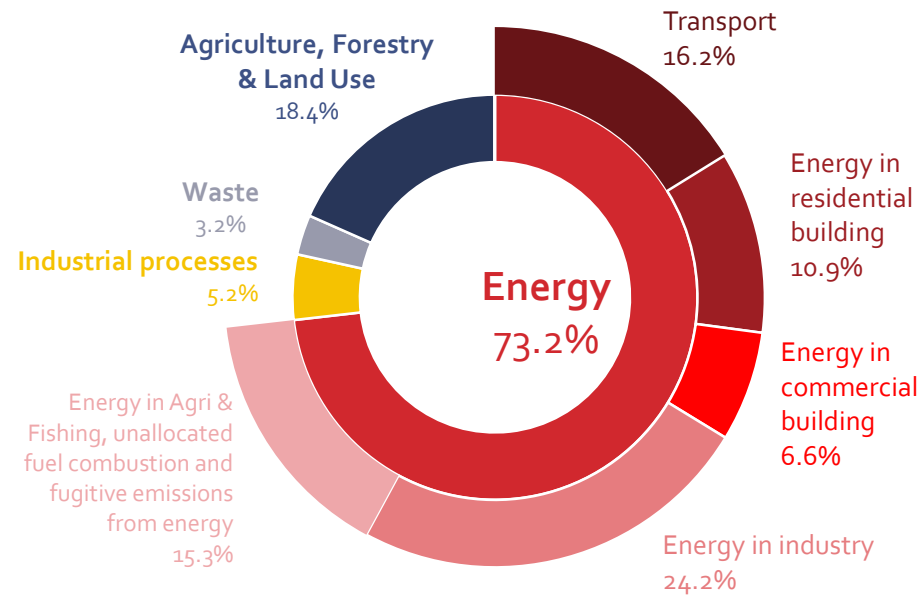

Figure 1. Sources of total $\mathrm{CO}_{2}$ worldwide $[25,26]$.

The use of coal massively increased the $\mathrm{CO}_{2}$ emissions in the world, especially in Asian countries. China, India, United States and the United Kingdom together has increased the world's $\mathrm{CO}_{2}$ emissions by $85 \%$. The use of coal in the energy mix is mainly driven by its attractive cost. Apart from that, the energy efficiency and weaknesses of current policies also further contributed to the rising of $\mathrm{CO}_{2}$ emissions in Asia [27,28].

ASEAN was one of the world's most diverse and rapidly rising economic regions in the 20th century [29-31]. Fossil fuels have traditionally dominated the energy mix in the region, making it amongst the largest GHG emitter and contributors to global warming [32-35]. Energy-related GHG emissions in the ASEAN region is forecasted to double by 2040, hitting 2.3 billion tonnes, unless substantial decarbonization in the fossil fuel energy mix can happen [36].

Figure 2 gives the ratio of various energy sources for electricity generation in ASEAN countries in 2017, with renewable energy covering hydropower, biomass, biogas, and solar energy. Coal is a major fossil energy source of electricity for numerous ASEAN countries such as Malaysia, Indonesia, the Philippines and Cambodia. Meanwhile, Singapore, Brunei, 
Thailand and Myanmar use natural gas as their primary fossil energy resource for electricity production [3,37]. Thailand is leading in non-hydropower renewable energy resources among the Asian countries. As a country of agriculture-based economy, Thailand has been successfully utilizing their agriculture waste as the main renewable energy resource and producing about $20 \%$ of electricity in their energy mix [38].

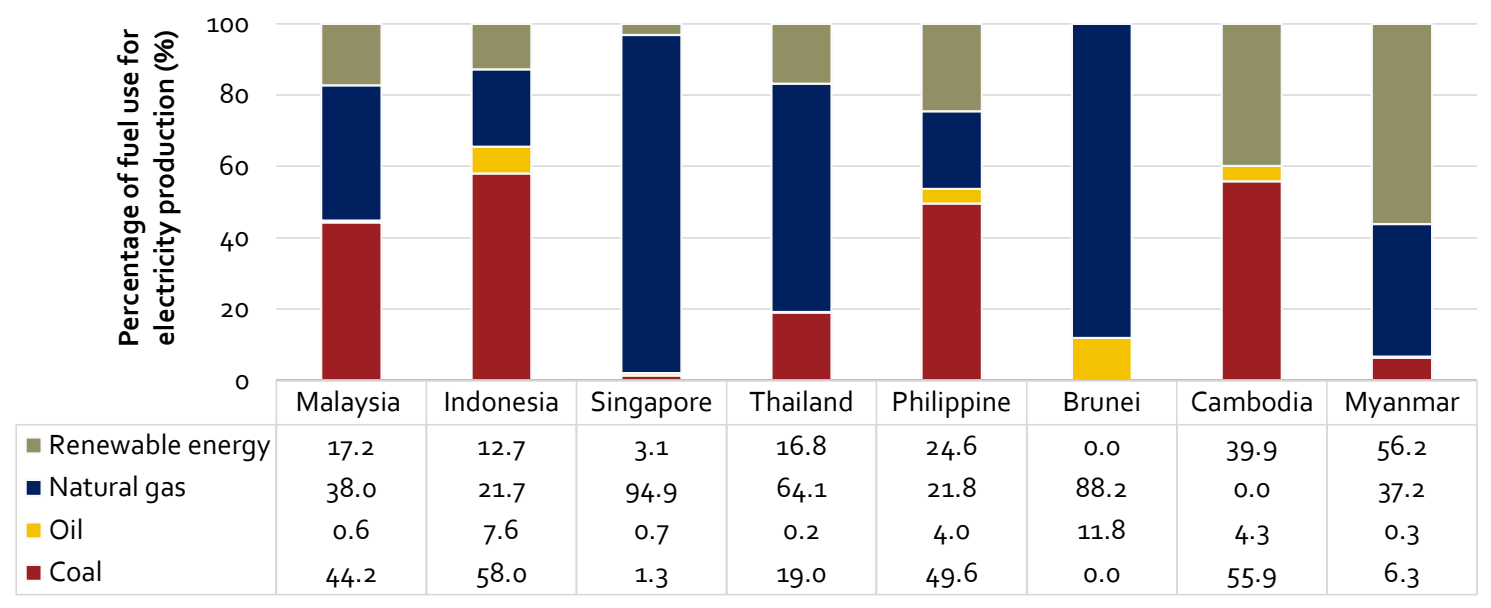

Figure 2. Percentage of energy inputs use for electricity production (\%) in ASEAN countries in 2017 [3].

Malaysia has been heavily dependent on fossil fuel resources for its energy input in power stations. In 2017, 82.9\% of the Malaysia energy mix was from fossil fuel, according to the capacity data from the Energy Commission of Malaysia [37], while the remaining 17.1\% is generated from renewable energy resources, mainly the hydropower. The fossil fuel energy input is made up of $44.2 \%$ of coal, $38.0 \%$ of natural gas and $0.6 \%$ of fuel oil/diesel. The contribution of other renewable energy besides the hydropower in energy mix of the year 2017 was only a mere $0.5 \%$.

Energy mixes tend to relate to a country's economic growth and energy demand. As a developing country, Malaysia has seen constant growth in energy demand due to the vast development in industrial, transportation, and agriculture sectors. In 2017, the energy demand for electricity in Malaysia stood at 12,605 ktoe (equivalent to 527,760 TJ), which has increased by $\sim 64 \%$ (4920 ktoe) since 2007 . The industrial sector has dominated the energy consumption by $49 \%$, followed by $30 \%$ from the commercial sector, $21 \%$ from the residential sector, $0.4 \%$ from the agriculture sector and $0.3 \%$ from the transportation sector as illustrated in Figure 3.

This paper will therefore concentrate on GHG emissions due to the electricity sector, since it is recognized as the primary emitter of the total global $\mathrm{CO}_{2}$ emissions. The structure of the industrial sector in energy consumption is shown in Figure 3, which is mainly from the cement industry (48\%) and steel \& iron industry (19\%) [39]. The transportation sector also showed a noticeable increment in energy demand from 2007 to 2017, which was from $0.05 \%$ to $0.3 \%$ of the total country demand. This is mainly due to the population increase as well as the income per capita of the country [40].

In order to analyse the energy mix in Malaysia, secondary data were used during data collection in the first part of this paper. Secondary data are accessed through publications, open literature, or LCA libraries [41]. It is regarded as a more cost-effective and nonreactive approach where information cannot be skewed and interpolated as a result of contact between the interviewer and the interviewees [42].

In this regard, data were assembled from the government documents, journals, published books, seminar presentations and unpublished materials and from government websites or other related websites. There are two significant areas for data collection, which are the upstream processes and the power generation processes. In this paper, only the power generation processes part will be discussed. 


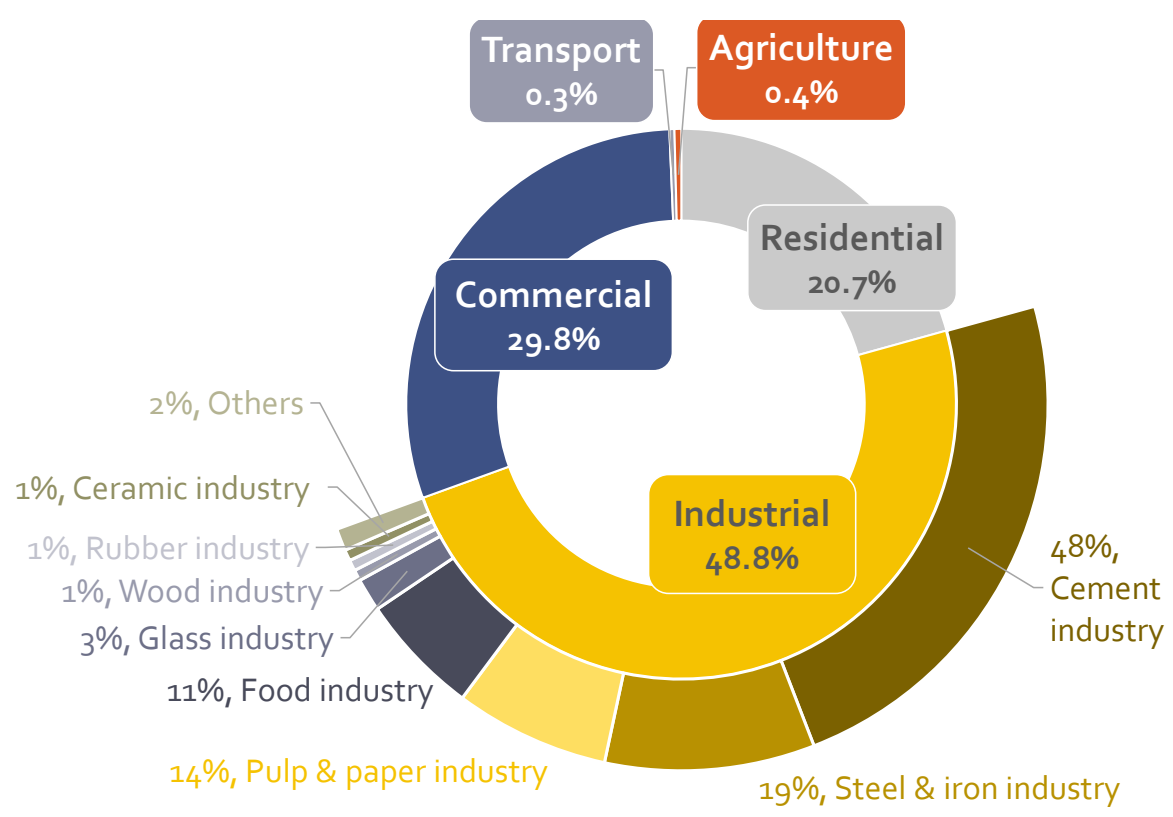

Figure 3. Energy demand in Malaysia [39,43].

\section{Energy Mix}

The information of power generation mix in Malaysia was gathered from the annual National Energy Balance (NEB) report of the Energy Commission of Malaysia [37]. It is worth mentioning that the Energy Commission of Malaysia also formed various cooperation arrangements to periodically supply the energy data to the relevant agencies such as the International Energy Agency (IEA), International Energy Forum Secretariat (IEFS), The Institute of Energy Economics, Japan (IIEJ), Asia Pacific Economic Cooperation (APEC), and the ASEAN Center for Energy (ACE). The data and information from the NEB report are claimed to be gathered from various agencies in Malaysia such as the government agencies, power utilities, independent power producers, oil companies, coal producers, cement, and iron as well as steel manufacturers [43].

\subsection{Energy Input in Power Stations}

The compilation of energy input trends in Malaysian power stations is summarised in Figure 4, and the percentage of each input at the selected year is given in Figure 5. Natural gas was the most significant resource for Malaysia's electricity generation back in 1995, followed by oil (diesel and fuel oil), coal, and hydropower station. The oil share in the energy input was about $21 \%$ in 1995, but vastly reduced to $2 \%$ in year 2010 and continuously reduced to $0.6 \%$ in 2017 .

On the other hand, coal usage has increased in the last two decades. In the year 2010, coal surpassed natural gas as the primary resources for electricity generation. The total percentage of natural gas consumption accounted for $57 \%, 75 \%, 62 \%, 46 \%, 40 \%$ and $32 \%$ in 1995, 2000, 2005, 2010, 2015 and 2017, respectively. Meanwhile, coal accounted for 9\%, $10 \%, 28 \%, 47 \%, 47 \%$ and $51 \%$ for the same period accordingly. Looking at the actual energy input in Figure 4, the consumption of natural gas has plateaued since the year 2000. Since then, the increase in Malaysia electricity demand was fulfilled by coal instead-indicated by its near linear increment between 2000 till 2017. 


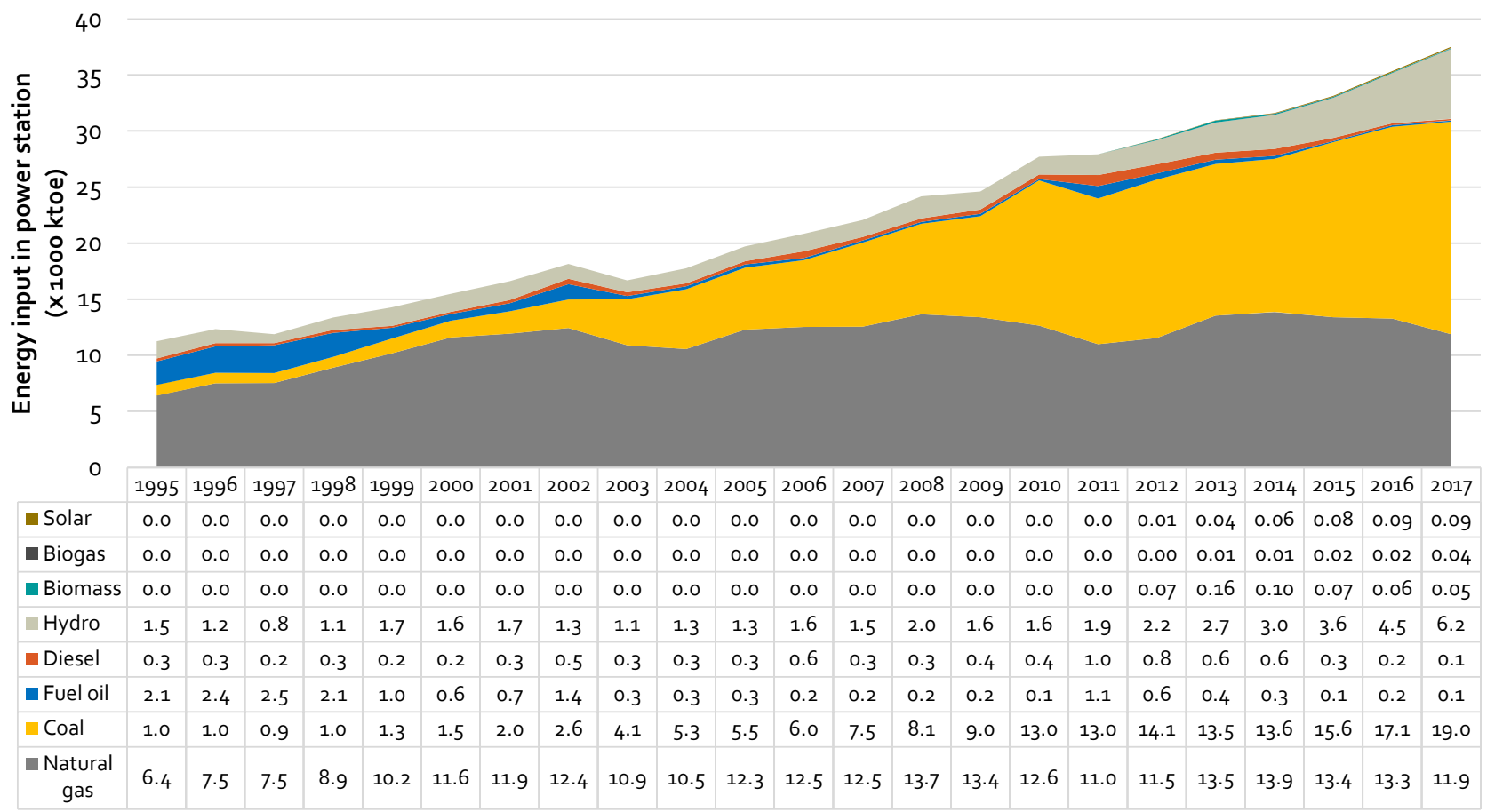

Figure 4. Energy input in power station from 1995 to 2017 [37,43].

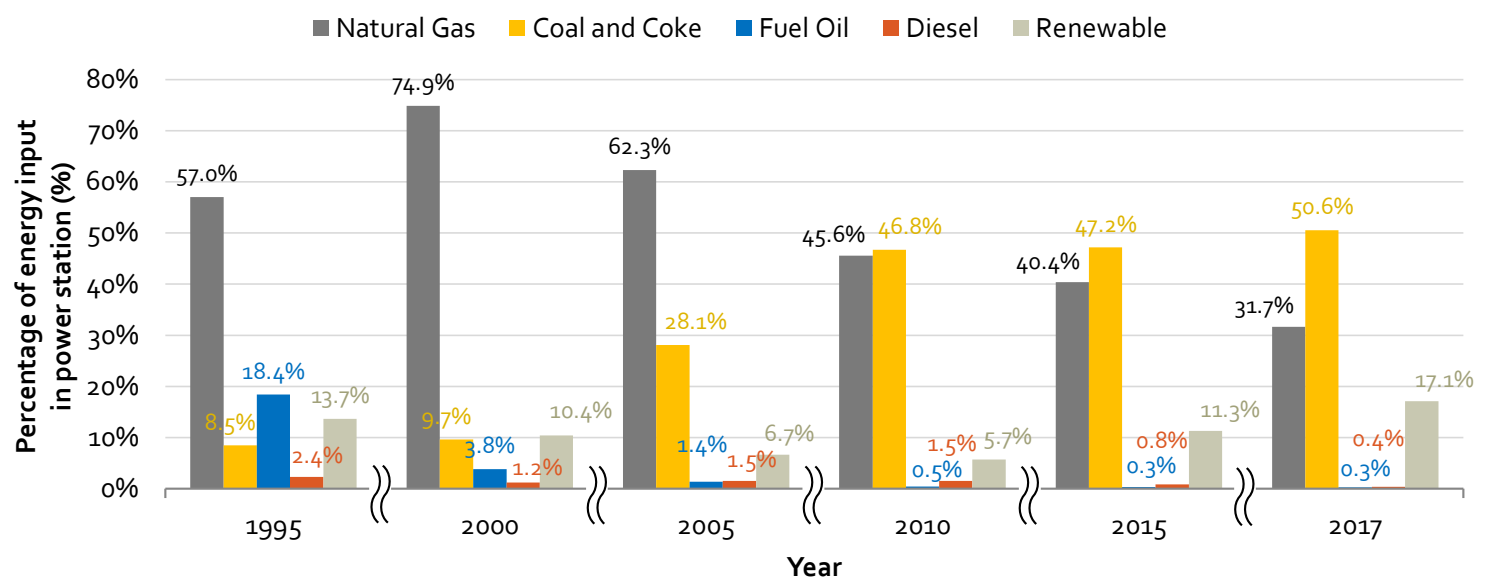

Figure 5. Percentage of energy input in power stations.

\subsection{Electricity Generation}

The trend for energy generation by different fuels in Malaysian power stations from 1995 to 2017 is summarised in Figure 6. Among the total electricity generation of 155.7 TWh in Malaysia during 2017, thermal power stations contributed the most, i.e., 128.9 TWh $(82.8 \%)$, whereas hydropower plants generated the remaining $26.8 \mathrm{TWh}(17.2 \%)$ [37]. In contrast, the electricity generated in 2000 was only $56.3 \mathrm{TWh}$, with the thermal power stations dominated by natural gas as the primary source at 49.9 TWh.

Back then, the hydropower station only contributed 7 TWh of the total electricity generation. Other renewable energy resources besides the hydropower only accounted for a very minute portion in Malaysia's energy mix. Most of the power stations in Malaysia are located in Peninsular Malaysia, which has highly concentrated population and industrial activities. On the other hand, Sabah and Sarawak are mostly depending on hydropower stations to generate electricity due to their favorable geographical terrains [44]. 


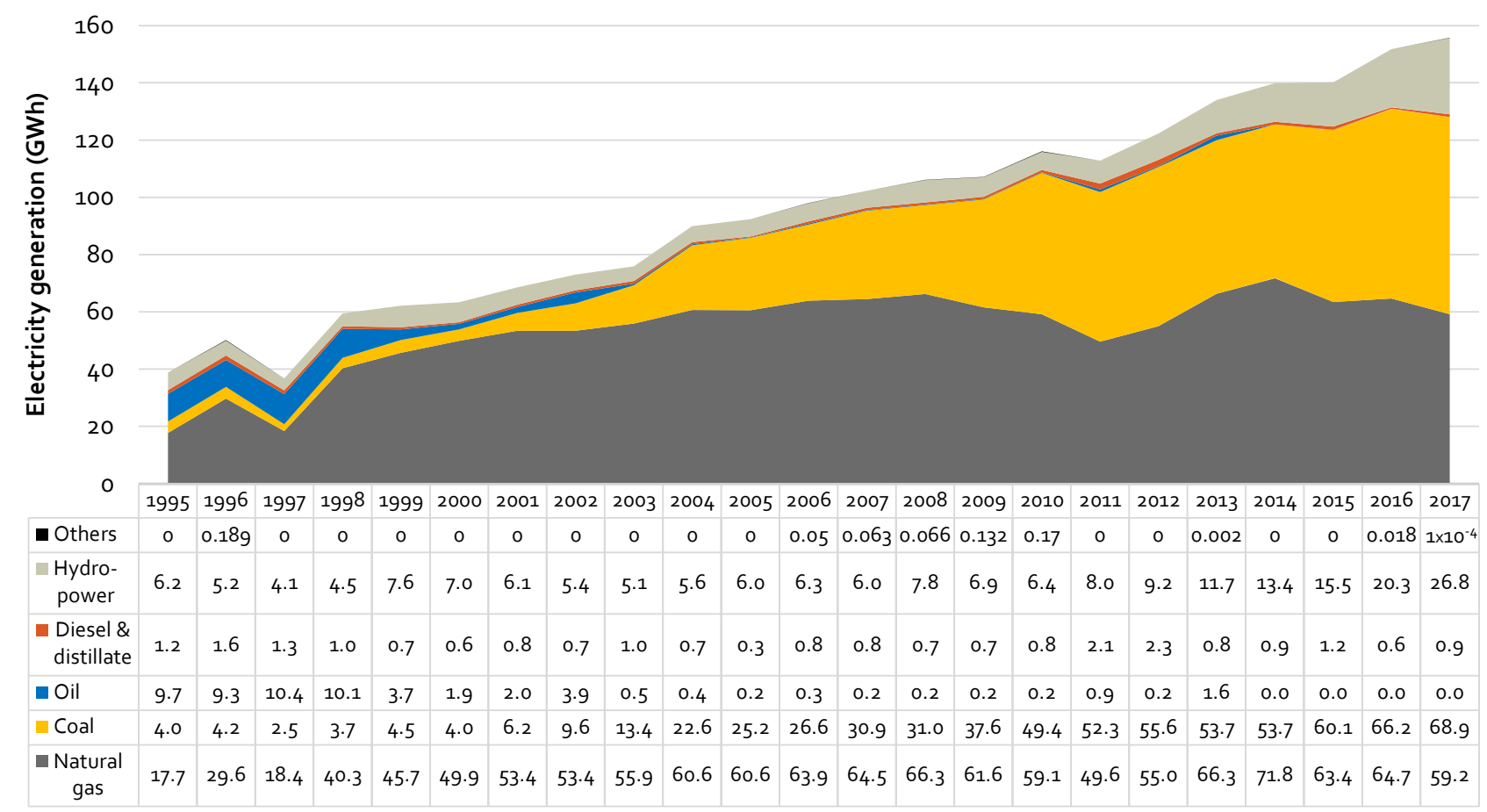

Figure 6. Electricity generation from 1995 to 2017 [37,43].

\subsection{Status of Energy Resources in the Power Generation Mix}

There are two main types of power plants available in Malaysia, namely the thermal (fossil fuel) and hydro power plants. From Figure 6, it can be seen that the power generation in Malaysia is predominantly relying on four major fossil fuel sources-coal, natural gas diesel and fuel-oil $[20,22,45]$. These fossil fuel resources, and some renewable resources such as the biomass, can be transformed into electricity at the thermal power plants, while the hydro power plants convert the potential energy of water heads into electricity by means of the hydraulic turbine.

The high energy demand and declining state of natural energy sources have turned into major concerns for energy industry players and policy makers alike. In order to improve the competitiveness and resilience of the economy, energy policy has gradually shifted its focus more on resources security, reliability and cost-effectiveness for energy supply [46].

\subsubsection{Energy Policies}

The energy policy in Malaysia could be loosely divided into two periods of time, as summarised in Figure 7, which is from 1975 to 2000 and from 2001 to 2011. The firstphase policies, initiated between 1975 to 2000, were intended to give an overview and direction to the energy sector in Malaysia. The existence of the National Energy Policy 1979 had outlined three main objectives, namely the supply objective, utilization objective and environmental objective [21]. The Four-Fuel Diversification Policy 1981 was then introduced to complement the National Depletion Policy 1979 to ensure the security and reliability of energy supply by diversifying the energy source.

The second-phase policy between 2001 and 2011 emphasises the role of renewable energy sources in the energy mix, green technology and environmental aspects of energy development $[21,44,47]$. The government also announced their pursuit of a green economy in the 11th Malaysia Plan 2016-2020, which changes the energy landscape in Malaysia to emphasise adopting the sustainable consumption and production concept [48]. The National Energy Efficiency Action Plan (NEEAP) 2016-2025 was also developed during this period highlighting three main key initiatives which are the Equipment Programme Initiatives, Industrial Programme Initiative, and Buildings Programme Initiative. 


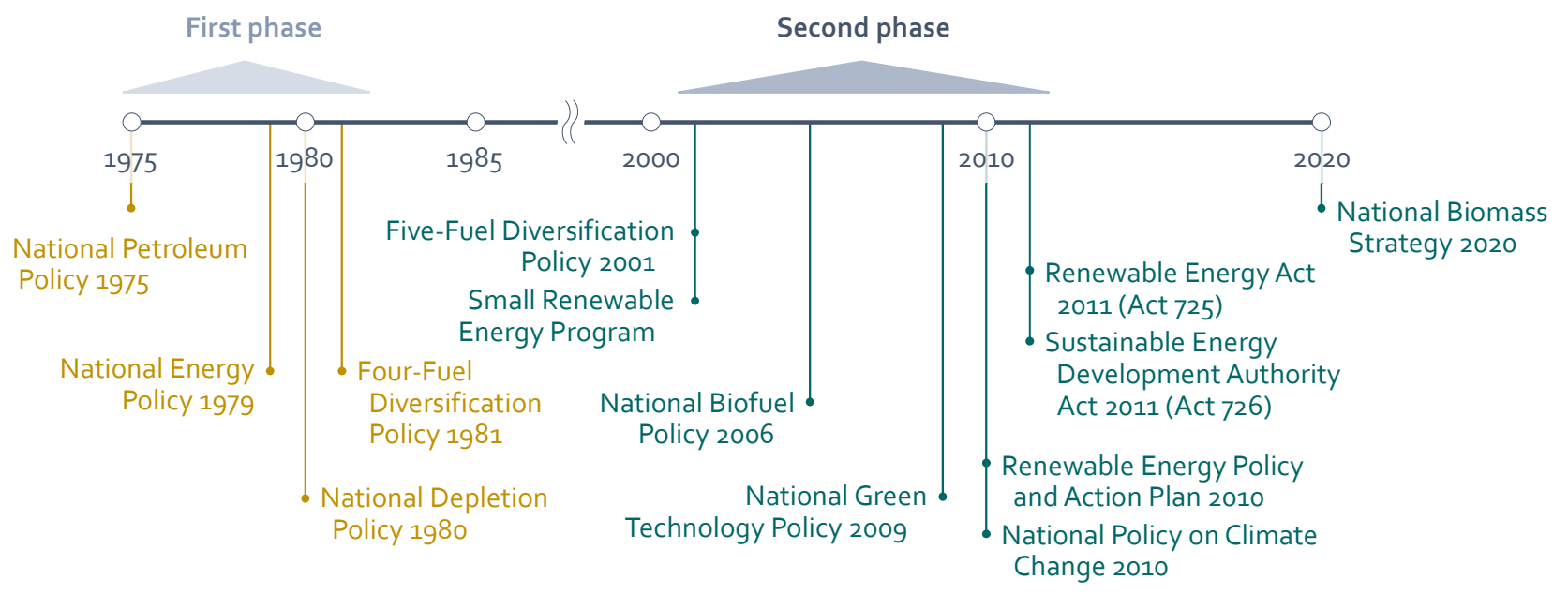

Figure 7. Summary of major energy policies in Malaysia from 1975 to 2020.

Malaysia is one of the countries that experienced drastic economic growth among the ASEAN members since the mid-1980s. Oil was the major source of energy in the early 1980s. However, the four fuel diversification policies introduced by the Malaysia government in 1981 reduced the oil consumption for that year [49]. The action was to balance the utilisation of other non-renewable energy sources, thereby ensuring the energy security and stability [20]. Furthermore, the oil prices started to increase since the 1980s, and the more economical natural gas became the primary choice for coping with the surge of electricity demand in the 1990s [23].

The fuel diversification policy in Malaysia was continuously reviewed to ensure that the country was not too dependent on one single source of energy, which was oil, with the concern of a possible prolonged energy crisis. Other options of energy resources available at that time were the large untapped indigenous hydropower and natural gas reserves, and abundant coal worldwide with relatively low and stable prices [50]. As a direct consequence of this strategy, the contribution of oil to the energy mix drastically dropped from a high of $90 \%$ dependence in 1980 to less than $10 \%$ in 2003 , and it continuously decreased to $0.7 \%$ by 2017 [18,37].

\subsubsection{Natural Gas}

As shown in Figure 6, the natural gas usage in the energy mix has seemed to plateau since 2010, for the simple reason that Malaysia was promoting fuel diversification in electricity generation. This move offered Malaysia the chance to free up more natural gas resources for exports and helped with the government's newly adopted policy of attempting to reduce its heavy reliance on natural gas for power generation [22]. In that context, the control usage of natural gas in power generation has different principles than the oil and diesel in the 1980s. Natural gas has a more stable yield compared to oil. Therefore, the production of natural gas has been found to increase steadily since the year 2000, despite the fact that the consumption at power station has been regulated.

The production, consumption and net exports of natural gas in Malaysia are given in Figure 8a. From the 2000 to 2005, the production level of natural gas has increased by nearly $23 \%$. In 2010, Malaysia was ranked as the world's ninth largest exporter of natural gas with about 1130 billion cubic feet of LNG being exported. Over time, the production and consumption of natural gas have reached near linear level trends, with the production exceeded the consumption by more than double; and their gap is showing a widening trend [46]. 


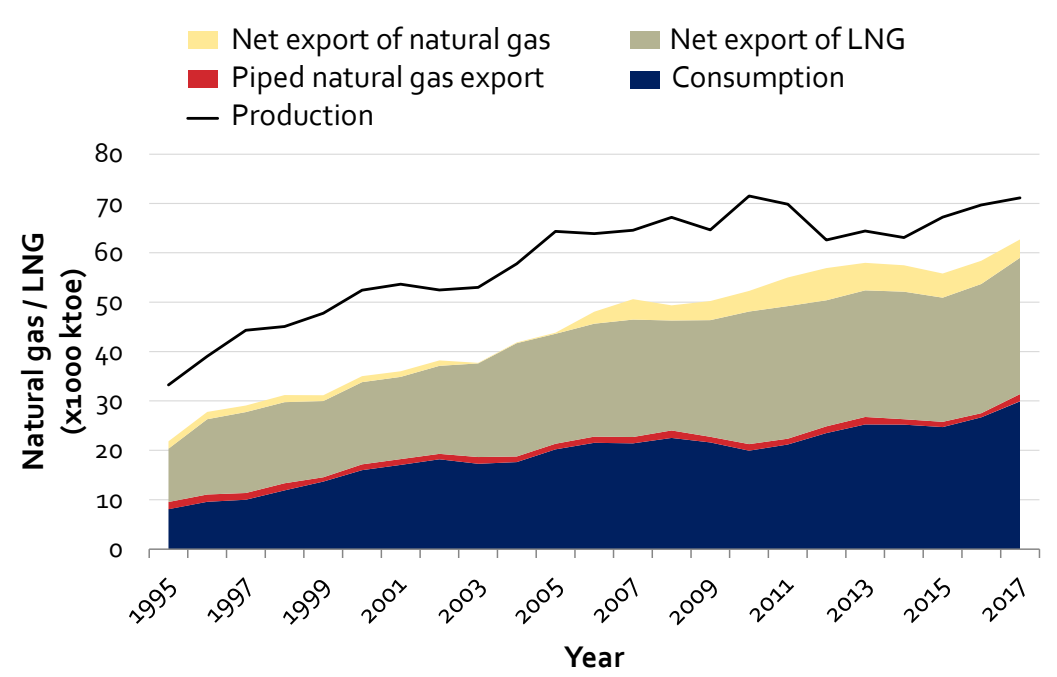

(a)

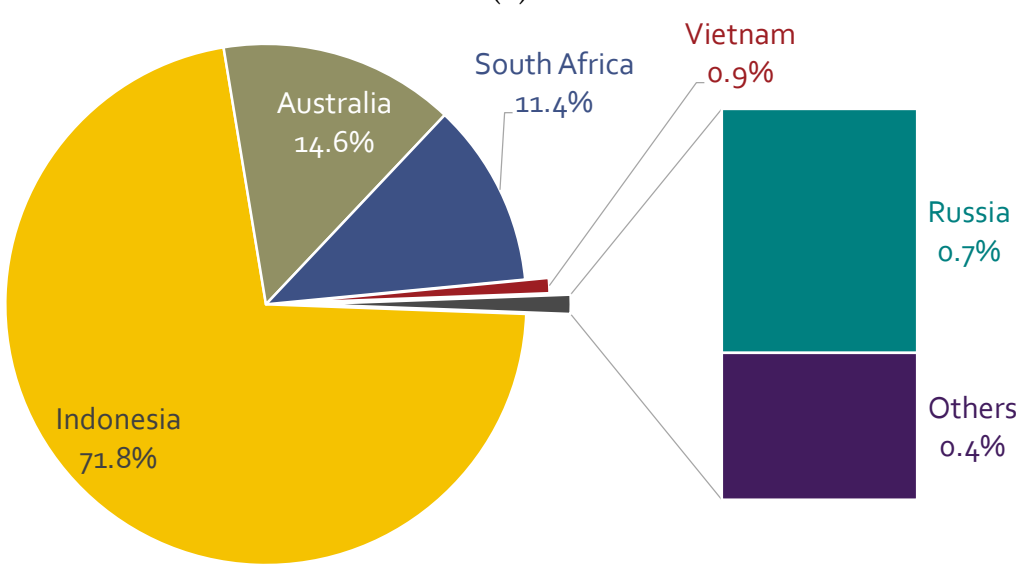

(b)

Figure 8. (a) Production, consumption, \& net exports of natural gas [37]; (b) coal import by country, averaged between 2011 to 2013 [51].

Globally, China and India have been developing energy strategies to simultaneously tackle the air quality, emissions and set expectations for continued energy demand growth. The switch from burning coal to natural gas in China is expected to see a drop in global GHG emissions and pollutants, including particulate matter. Both countries view the use of imported natural gas for cooking and transportation, as well as increasing the usage in solar power as a way to reduce air pollution [52].

\subsubsection{Coal}

The use of coal in the energy mix is mainly driven by its attractive cost in 2010 . Besides further distributing the dependency on a single energy resource, it also helps the government to rationalize the nation's electricity tariff. de Oliveira [53] also reported that the selection of coal as the primary source in the energy mix was also partly due to political involvement. Nonetheless, the use of coal in the energy mix has raised worry worldwide for its detrimental impact on the environment.

Bituminous and sub-bituminous coals are the most common type of coal found in Malaysia, with the latter being more predominant [54,55]. Sub-bituminous coal is generally used for electricity generation, which contains $35-45 \%$ of carbon. Bituminous coal has a much higher carbon content (45-86\%), and is also used as the fuel for electricity generation, and is sometimes referred to as the coking coal in steel production [56]. 
Almost $98 \%$ of the coal reserves in Malaysia are on the island of Borneo, which is in the Sabah and Sarawak region, though these states were utilizing mostly hydropower generation. Only 2\% of coal reserves are found in Peninsular Malaysia, where energy demand is high and most of the coal fields are located inland with poorly developed infrastructure [54].

On paper, Malaysia has sufficient coal resources to meet its local demand in comparison with other natural sources. However, $90 \%$ of the local coal demands were still imported from other countries, primarily from Indonesia, Australia, and South Africa, as shown in Figure $8 \mathrm{~b}$ [51]. One of the most important factors contributing to this particular scenario is the high extraction and transport cost of local coal. Most coal deposits in Malaysia require underground mining, hence they are less cost effective compared to importing the surface mined coal.

As the prices for renewable power worldwide are plummeting and technologies for storage are becoming more cost-effective, coal is becoming comparatively expansive for generating electricity [57]. This is anticipated to alter the global energy mix significantly, but perhaps not so much for Malaysia since 15-year affreightment contracts for long-term coal supply have just been put in place in 2016 [58]. That said, no new coal power plant will be expected until 2025. It may be seen in Figure 9 that the known 5-year plan for Malaysia 7840 MW power generation capacity expansion is dominated by natural gas and renewable energy.

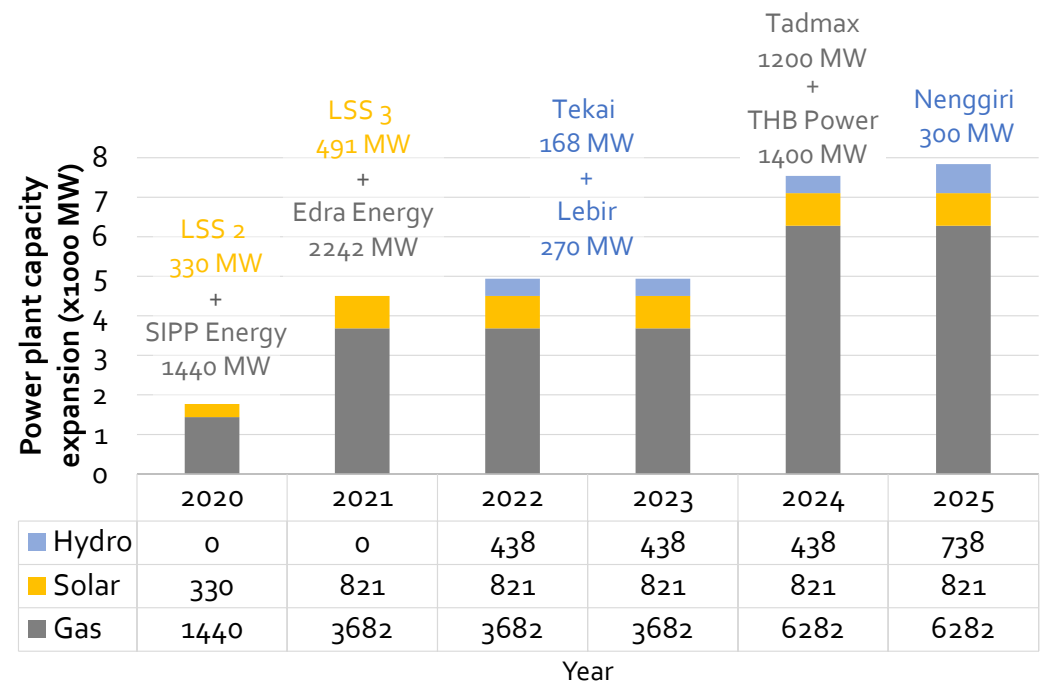

Figure 9. Malaysia power plant capacity expansion plan till 2025 [59].

Nonetheless, the global coal demand is expected to remain largely stable over the next five years, owing to robust growth in major Asian markets. Countries in Southern and Southeast Asia, such as India, Indonesia and Vietnam, have been heavily relying on coal to boost their economic development. Pakistan and Bangladesh are historically relied on natural gas and oil for power generation but have opted for large-scale coal power generation to cope with the nations' electricity surge in recent years [3]. On the contrary, coal power production is declining in Europe and the United States to levels not seen in decades, due to low natural gas prices, stagnant electricity demand, and the vast growing solar and wind energy. This trend is expected to continue through 2024.

\subsubsection{Renewable Energy}

The Malaysian government has set an enthusiastic target to achieve a higher infusion of Renewable energy in Malaysia's energy mix since 1980 [60]. Renewable Energy Act was gazetted in 2011, which introduced the implementation of Feed-in Tariff (FiT) and the renewable energy smart target. In 2018, the government targeted to achieve $20 \%$ of renewable energy in the energy mix by the year 2025 [48]. Malaysia's renewable energy mix consists of hydropower, biomass, biogas, and solar energy. 
Hydroelectricity represents the largest portion of renewable energy in the power generation mix. This is because nearly all the states in Malaysia have the potential for hydropower, especially Perak, Pahang, Sarawak and Sabah. The average annual rainfall in Peninsular Malaysia, Sabah and Sarawak are about $2540 \mathrm{~mm}, 2630$ and $3850 \mathrm{~mm}$, respectively, due to the monsoon season [61]. This made up the abundant water resources of Malaysia for hydroelectricity generation.

Hydropower creates a unique "techno-political" situation in which nature becomes economically and financially efficient, opening up new possibilities for economic growth [62]. The Iron Gates Dam in Romania and Yugoslavia is among the most representative hydropower projects when examining the economic and political relations underpinning industrial development [63]. It demonstrates the critical role of political power and diverse institutional settings in the production of hydropower [64].

On the other hand, the Three Gorges Dam in China is one of the largest hydroelectric dams in the world [65], but poses several environmental issues, including water quality control and ecological problems. The dam-building significantly impacts the river processes, its related habitats and landscapes, and alters the water chemistry. The Yangtze River basin is one of China's most economically developed and densely populated regions, thus environmental quality management is critical for long-term economic growth [66].

Other than hydroelectricity, Malaysia has also started to explore biomass product for electricity generation at an industrial scale [67]. Biomass is a natural, renewable carbon resource derived from living or dead organisms and organic materials that consist of chemical energy content. It is the fourth largest energy resource in the world and abundantly found in Malaysia, though has not been fully capitalized.

Palm oil is a major contributor to the production of biomass in Malaysia. As the world's second-largest palm oil producer, Malaysia processes about 71.3 million tonnes of fresh fruit bunches on average every year. As a result, 19 million tons of crop residue consisting of empty fruit bunches, fibres and shells were produced. In addition to the agricultural waste generated from palm oil, forest waste and municipal solid waste are also the sources of biomass in Malaysia [68]. Among the green energy policies implemented by the Malaysian government between 2001-2011, there are five that highlighted biomass as an alternative renewable energy source to drive the local industry. Consequently, electricity generated from biomass resources has started in 2012 with a power station input of 65 ktoe.

Conventionally, biomass is converted into briquettes, a dry, blackened material with high energy density via the torrefaction process [69]. The briquettes can then be burned directly, and energy conversion is realised through the steam power plant. Alternatively, biomass can be made into biogas via the anaerobic digestion of the organic substrates, where the complex organic material is dissolved in the presence of anaerobic microorganisms [70]. The main composition of biogas is $\mathrm{CH}_{4}$ (and $\mathrm{CO}_{2}$ ), hence energy conversion can be accomplished through a gas turbine power plant that has higher thermal efficiency compared to the steam counterpart. This proved to be a more favourable fuel source as could be seen from the steady increment in biogas usage since the 2012 in Figure 4.

The biggest concern of biogas is obviously its production process and storage since its main composition also happens to be the main source of GHG emission. Another complication with biomass/biogas industry is in the procurement of feedstock, where unregulated feedstock prices may quickly deteriorate the interest in its usage. The Malaysian government has been looking at the feasibility of turning biowaste into a commodity to resolve this situation [71]. Besides the economical difficulty, the technological development of gas turbine in handling fuel of a much wider spectrum of physical and chemical properties is also vital in promoting the usage of biomass and biogas [72].

The activity and maintenance of biogas plants are crucial to their long-term viability. A sustainable biogas plant needs to be professionally constructed to avoid failures caused by shoddy workmanship. Numerous biogas plants worldwide have been shut down, due to leakage in a reactor as a result of a variety of factors, including sub-standard construction materials, excessive biogas strain, unskilled labour, and substandard piping [73-76]. 
Biomass energy is often regarded as problematic because of its complexity and interaction with a variety of different fields of study, including land use, forestry, livestock, animals and societal factors. The provision and use of biomass energy is only a subset of a more complicated issue surrounding the preservation of all forms of vegetation, which is a necessary component of ensuring stable socio-economic growth [77].

Solar energy is another great energy resource for electricity generation in Malaysia. Being close to the equator, Malaysia benefits from solar rays all year round, making solar energy a very viable generation resource. Solar energy has been popular renewable energy lately due to its simplicity in comparison to other renewable energy (i.e., hydro, wind and wave) that required complex mechanical systems for producing electricity. The use of solar energy began in 2012 with an input of 12 ktoe (Figure 4) and has steadily increased by six-fold to 93 ktoe in 2017.

In the early 2010s, the primary limitation of solar energy utilisation was its relatively expansive cost-to-power density ratio that leads to high capital investment [78]. However, the solar cost has drastically dropped by a factor of 5 since 2010, even less than coal in Europe. This has been attributed to the massive expansion of the solar industry economy of scale $[79,80]$. That said, the hazardous production process and short life expectancy of the solar module are foreseen to trigger a set of new environmental problems in the very near future [81].

In Malaysia, solar energy has been widely used along the North-South Expressway, telecommunication towers, and even street lighting [82]. The aforementioned Feed-in-Tariff (FiT) program further encourages solar energy usage by offering a long-term contract and guaranteed pricing to the producers of renewable energy, who could be any home or business owners and private investors, where they will be compensated for the renewable energy they have produced [83]. In addition, the initiation of 1400 MW Large-Scale Solar (LSS) project, shown in Figure 9, is expected to further increase the solar energy share in Malaysia energy mix in the coming decade [84].

Solar energy is becoming more widely used in urban areas, but its implementation requires comprehensive urban planning. This must consider the relationships between solar energy and urban morphology [85-87], implications for technological strategies used, solar accessibility, and solar energy potential [88]. Often in practice, more technical and non-technical obstacles in the planning process such as land use and architectural integration $[88,89]$, technology and energy problems, as well as social, environmental, and economic barriers must be overcome $[90,91]$.

\section{Greenhouse Gas (GHG) Emissions}

Electricity generation accounts for the largest share of Malaysia GHG emissions. As a developing country, rising energy demand has pressured the government to select cheaper sources of energy for power generation [92]. The concern over GHG emissions has been a debatable topic among climate change communities, mainly surrounding the release of $\mathrm{CO}_{2}$ generated through power generation being unsustainable for the environment [93].

The emission level of Malaysian industries is governed and monitored by the Department of Environment Malaysia. However, unlike the energy mix data, the emission data were categorized as non-disclosure information by the Department of Environment Malaysia, thus not being accessible by the public or in this study. Hence, the next reliable approach was taken for the second part of this paper, which is via calculation rather than secondary data gathering. A comprehensive emission calculation methodology for stationary combustion, covering three major GHGs of the combustion process $\left(\mathrm{CO}_{2}, \mathrm{CH}_{4}\right.$ and $\mathrm{N}_{2} \mathrm{O}$ ), has been outlined by IPCC [94].

In general, the emissions of each GHG from the stationary sources are calculated via multiplying fuel consumption by the corresponding emission factor. The fuel consumption is estimated from the energy input statistics in Figure 4, measured in TJ. The emission factor for stationary combustion extracted from IPCC [94] is given in Table 1. 
Table 1. Emission factors for stationary combustion in the energy industries [94].

\begin{tabular}{lccc}
\hline Fuel Type & $\begin{array}{c}\mathrm{CO}_{2} \\
\mathbf{( k g / T J})\end{array}$ & $\begin{array}{c}\mathrm{CH}_{4} \\
\mathbf{( k g / T J})\end{array}$ & $\begin{array}{c}\mathbf{N}_{2} \mathbf{O} \\
\mathbf{( k g} / \mathbf{T J})\end{array}$ \\
\hline Natural gas & 56,100 & 1 & 0.1 \\
Residual fuel oil & 77,400 & 3 & 0.6 \\
Diesel oil & 74,100 & 3 & 0.6 \\
Other bituminous coal & 94,600 & 1 & 1.5 \\
Sub-bituminous coal & 96,100 & 1 & 1.5 \\
Industrial waste (Biomass) & 143,000 & 30 & 4 \\
Other biogas & 54,600 & 1 & 0.1 \\
\hline
\end{tabular}

\subsection{Carbon Dioxide, $\mathrm{CO}_{2}$ Emission}

$\mathrm{CO}_{2}$ emission has the greatest direct global warming contribution because of its high natural concentration measured in parts per million (ppm) of air. MESTECC [95] (currently known as KASA) stated that $55 \%$ of the total $\mathrm{CO}_{2}$ released in 2011 was contributed by the electricity industry, followed by $22 \%$ from the automobile sector and $11 \%$ from the manufacturing and construction sector. Even in 2013, the electricity industry was still the biggest contributor with $46 \% \mathrm{CO}_{2}$ emissions. Therefore, it is undeniable that the energy sector is the largest contributor to GHG emissions in Malaysia.

Figure 10a shows the calculated total annual of $\mathrm{CO}_{2}$ emission at power plants throughout Malaysia, categorized by resource, from 1995 till 2017. The annual $\mathrm{CO}_{2}$ emission has shown an increasing trend ever since year 1995, in the same trend as the energy input in Figure 4. The emissions of $\mathrm{CO}_{2}$ from natural gas power station have been found to flatten since the year 2000, when coal became the primary power generation resource. This led to the rise of $\mathrm{CO}_{2}$ emissions by coal from the year 2000 onwards. Huda et al. [96] reported that the coal projects in thermal generation from 1997 till 2010 to cope with the surge in energy demand, such as the two $700 \mathrm{MW}$ coal-fired power generation in Negeri Sembilan, had increased the $\mathrm{CO}_{2}$ emission by 8.5 MTon within the range of 13 years.

The switch in the usage of coal in the energy mix has certainly altered the pattern of $\mathrm{CO}_{2}$ gas emission in Malaysia, and the trend continues to grow since it was reported a decade ago [97]. On the other hand, the $\mathrm{CO}_{2}$ emission from diesel and fuel oil remain the minority compared to the natural gas and coal due to their low generation capacity.

The $\mathrm{CO}_{2}$ emission plot in Figure 10a is subjected to the variation in energy input between resources. In order to evaluate the emission performance of each fuel, it is necessary to normalise the emission data in Figure 10a to a common ground. Thus, the $\mathrm{CO}_{2}$ emission per unit $(1 \mathrm{kWh})$ electricity generation, referred to as the specific $\mathrm{CO}_{2}$ emission. Unlike the conventional emission intensity/factor in Table 1, this parameter is computed relative to the generation (output) energy, thus taking into account the efficiency of thermal conversion. This is computed here for each resource and shown in Figure 10b.

Looking at the two primary resources of Malaysia energy mix, coal is consistently having higher specific $\mathrm{CO}_{2}$ emission compared to natural gas. The difference is close to nearly twice as much throughout the last two decades. This is likely to relate to the energy content of these fuels. The energy content of coal is around $24 \mathrm{MJ} / \mathrm{kg}$, about half of the $42-55 \mathrm{MJ} / \mathrm{kg}$ from natural gas. Hence, it is expected to consume twice as much coal (by mass) in producing the equivalent generation energy as natural gas, thereby doubling the specific $\mathrm{CO}_{2}$ emission. 


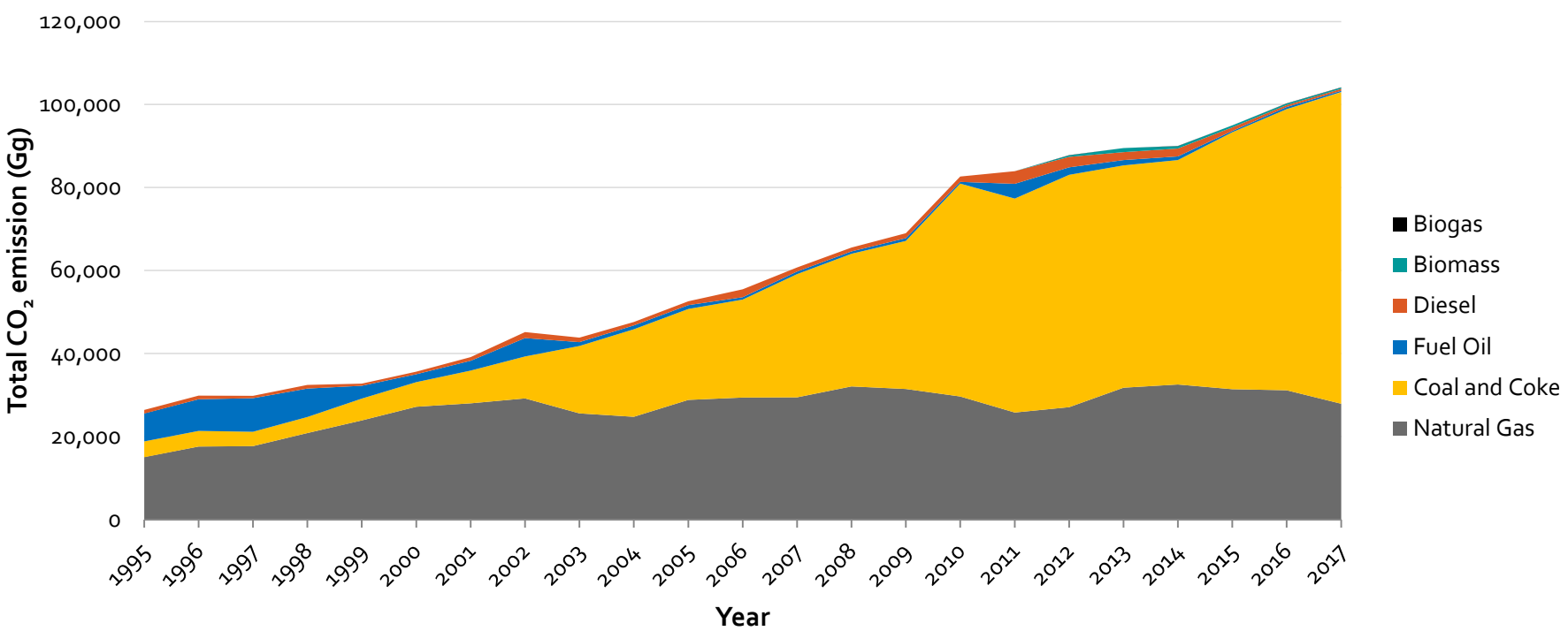

(a)

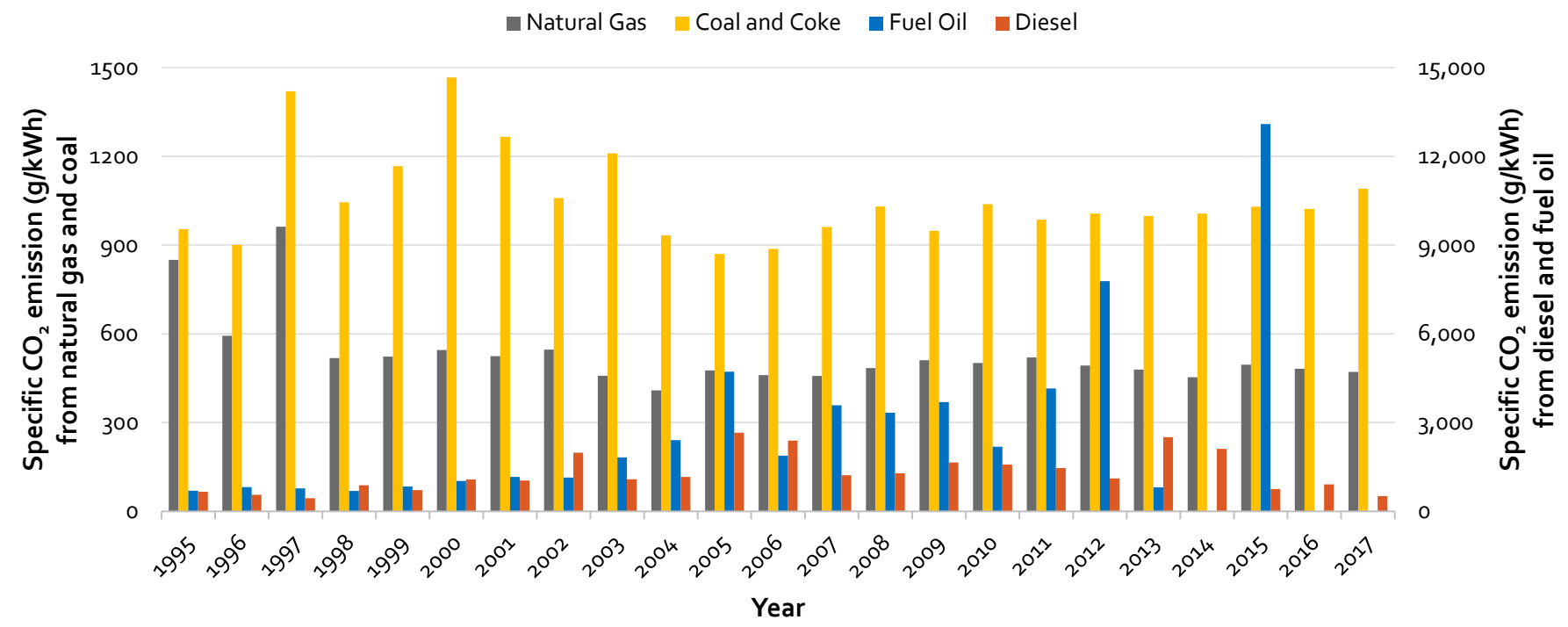

(b)

Figure 10. (a) Total annual and (b) specific $\mathrm{CO}_{2}$ emissions from Malaysia electricity generation sector from 1995 to 2017.

Another indication from the specific $\mathrm{CO}_{2}$ emission plot is the power plant conversion efficiency-higher specific emission indicates poorer energy conversion in the power plant. It may be observed that the specific $\mathrm{CO}_{2}$ emission of natural gas has been fairly stable since 1998 till recently. On the contrary, specific $\mathrm{CO}_{2}$ emissions of coal power plants were rather unstable in the 1990s and only began to decrease since 2004, four years after the Malaysia government's policies in promoting fuel diversification that led coal to be the primary resource in electricity generation.

On the other hand, the specific $\mathrm{CO}_{2}$ emissions of diesel and fuel oil are highly fluctuating throughout the year. In particular, they were found at different magnitudes than the natural gas and coal, and hence were plotted on a separate scale in Figure $10 \mathrm{~b}$ to ensure the readability of other plots. This happened because of the mismatch in the energy input and energy generation data in Figures 4 and 6.

Unfortunately, there was no conclusive explanation on this phenomenon. According to the unofficial explanation from the Energy Commission of Malaysia, it was because diesel and fuel oil were mainly used by remote (independent) generator sets, where their usage/generation data could not be documented properly. As a result, these results are 
less reliable and will not be discussed much here. Nonetheless, the contributions of diesel and fuel oil in the energy mix are very minute compared to natural gas and coal, thus less critical in the current analysis.

The motivation of using coal as the primary generation resource in the year 2000 was also partly driven by its cheaper cost compared to natural gas. Figure 11a gives the comparison on unit cost of each resource (for $1 \mathrm{TJ}$ of electricity input energy) in Malaysia Ringgit (MYR) [98]. Due to the availability of data, the unit costs for natural gas and coal are shown from the year 2000.

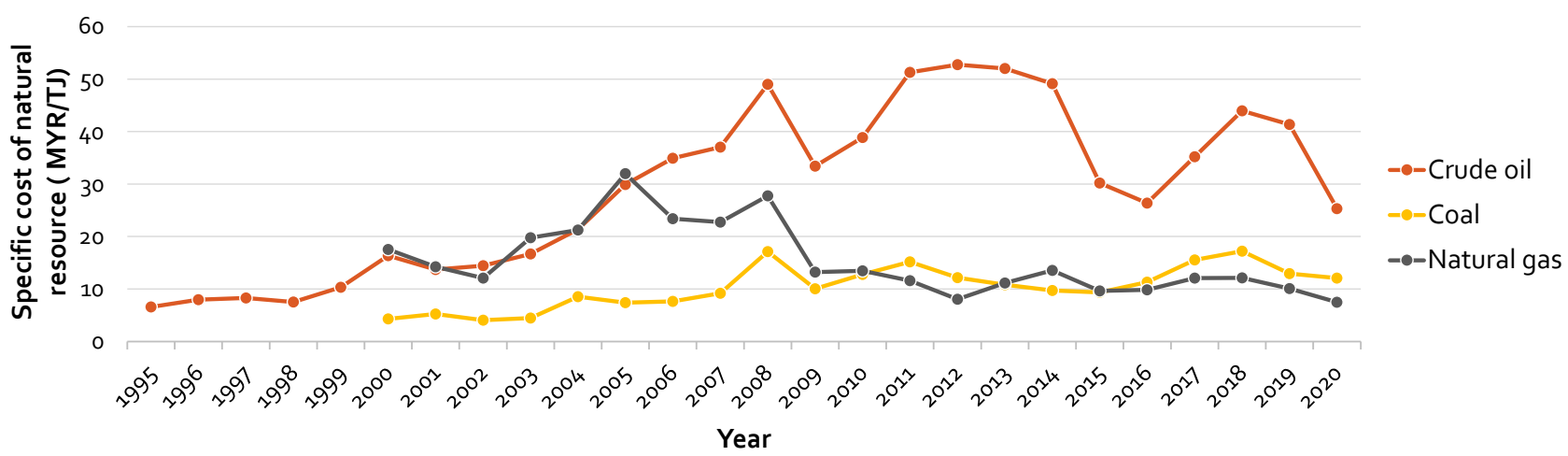

(a)

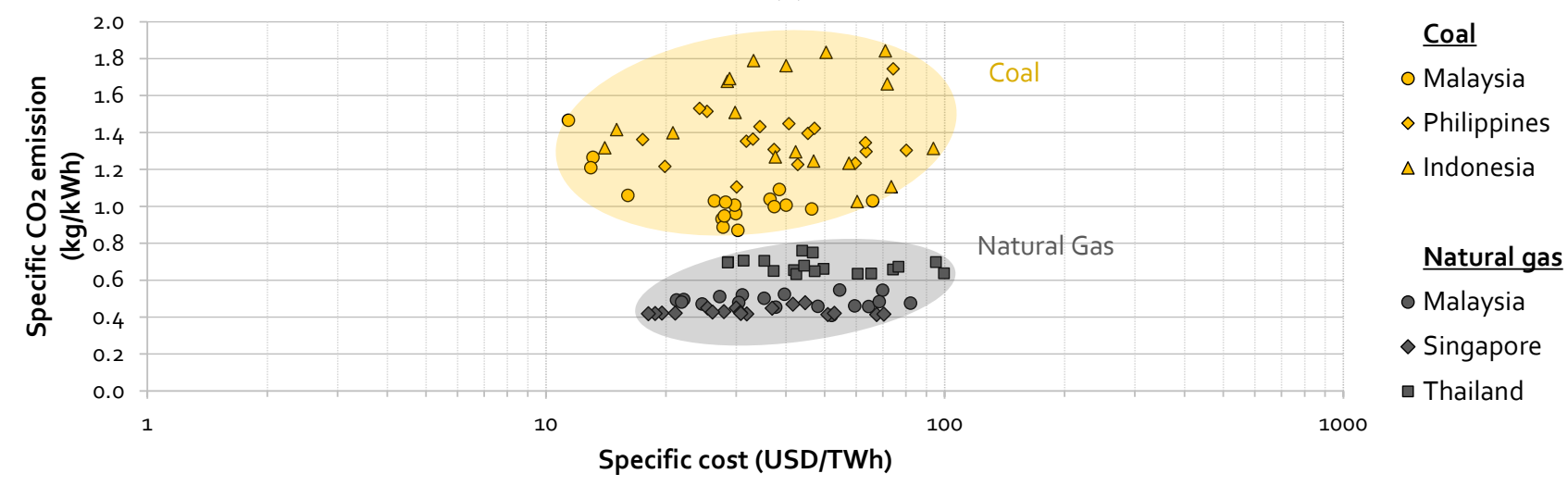

(b)

Figure 11. (a) Specific cost of resource for $1 \mathrm{TJ}$ of energy input (MYR/TJ); (b) specific cost (USD/TWh) and specific CO 2 emission $(\mathrm{kg} / \mathrm{kWh})$ of natural coal and coal for ASEAN countries.

In the early 2000s, the unit cost of natural gas was nearly triple that of the cost for coal. This explained the government's initiative in moving into coal for energy generation. However, the price of petroleum products suffered a massive drop following the 2008 financial crisis [99,100]. While the price of diesel managed to recover by the year 2011, the unit cost of natural gas remained low and comparable to coal since then.

In addition, the strong growth in the production has also contributed to stabilising the natural gas price [101]. All these have diminished the initial attraction of using coal as the primary energy input. It is also worth mentioning that the price of diesel from Figure 11a is highly subjected to the fluctuation in market supply, demand and political moves, including the lowest price seen in 2016 due to global oversupply [102].

The specific cost of energy input (actual cost computed using the energy input data from Figure 4 divided with the generation data from Figure 6) and the specific $\mathrm{CO}_{2}$ emission for various energy resources is compared in Figure 11b. Besides the Malaysia data, the energy data of primary energy input for few other ASEAN countries are also included here. Since the comparison is conducted across different countries, the currency is expressed in US dollars instead. 
It is apparent from Figure $11 \mathrm{~b}$ that natural gas is having clear advantage in specific $\mathrm{CO}_{2}$ emission over coal. On average, the specific $\mathrm{CO}_{2}$ emission of coal across Malaysia, Indonesia and the Philippines is around $1350 \mathrm{~g} / \mathrm{kWh}$. This is nearly 2.5 times greater than the averaged specific $\mathrm{CO}_{2}$ emission of natural gas from Malaysia, Singapore and Thailand. It is worth noting that the power plant conversion efficiency of these countries, for each energy resource, is highly comparable among them; with coal power plant having $\sim 24.7 \%$ of averaged conversion efficiency and natural gas $\sim 38.7 \%$.

The specific costs in Figure $11 \mathrm{~b}$ is obviously varying across a fairly wide range, due to the fluctuation of market prices of these resources. Therefore, natural gas is now becoming the more favourable fossil fuel resource - not only its specific cost is comparable to coal, but the specific $\mathrm{CO}_{2}$ emission is also significantly lower.

\subsection{Methane, $\mathrm{CH}_{4}$ Emission}

The total annual $\mathrm{CH}_{4}$ emission from Malaysia electricity generation sector is given in Figure 12a from 1995 to 2017. The $\mathrm{CH}_{4}$ emissions are showing an increasing trend over the years, in line with the electricity consumption shown earlier. The majority of the $\mathrm{CH}_{4}$ emission is thought to be man-made, such as the systemic leakage during coal mining and from oil wells, anaerobic decomposition of organic waste including the production of biogas and biomass burning (charcoal combustion, forest fire, etc.) [103,104]. $\mathrm{CH}_{4} \mathrm{emission}$ is well known for its dreadful impact to the earth ozone depletion. Although the magnitude of $\mathrm{CH}_{4}$ emission in Figure 12a is $\sim 1 / 100,000$ of the $\mathrm{CO}_{2}$ emission in Figure $10 \mathrm{a}, \mathrm{CH}_{4}$ could be 105 times more harmful than $\mathrm{CO}_{2}$ emission, and thus should not be undermined in anyway [105].

Figure $12 \mathrm{~b}$ shows natural gas and coal is emitting equivalent specific $\mathrm{CH}_{4}$ emission. The $\mathrm{CH}_{4}$ emission from coal is primarily produced during the coal mining process rather than during its combustion, and deep mining is producing twice as much $\mathrm{CH}_{4}$ as surface mining [106]. On the other hand, $\mathrm{CH}_{4}$ emission from natural gas is almost exclusively due to systemic leakage, often resulting from immature extraction technology $[107,108]$.

Systemic leakage at this scale could potentially emit equivalent or higher amount of $\mathrm{CH}_{4}$ than $\mathrm{CO}_{2}$ during its combustion. In the United States, the $\mathrm{CH}_{4}$ emission has increased by $27 \%$ (39 MMTCO2e) from 1990 to 2009 due to the increase in natural gas consumption [109]. Therefore, the use of natural gas as primary energy mix should take appropriate risk assessment into consideration despite its superior specific $\mathrm{CO}_{2}$ emission.

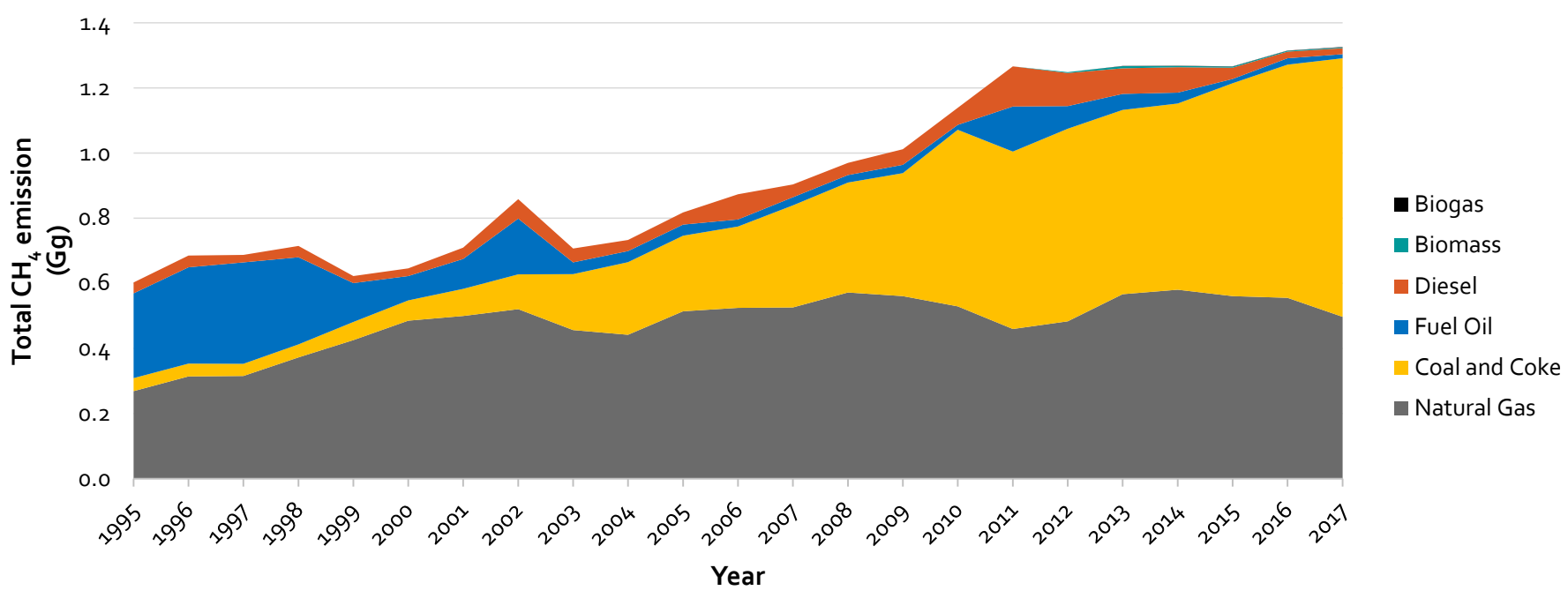

(a)

Figure 12. Cont. 


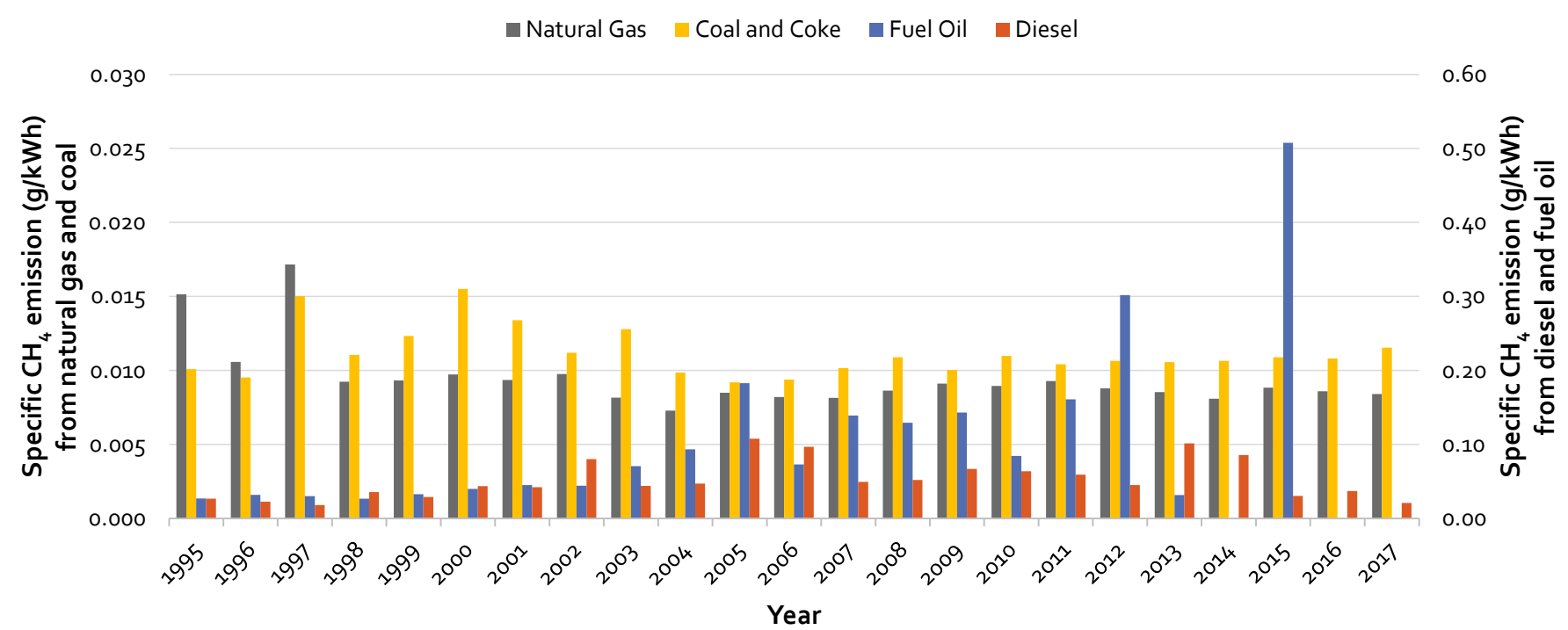

(b)

Figure 12. (a) Total annual and (b) specific $\mathrm{CH}_{4}$ emissions from Malaysia electricity generation sector from 1995 to 2017.

Oil and gas operations are likely the largest source of $\mathrm{CH}_{4}$ emissions from the energy sector as compared to coal and biofuels [3]. Global oil- and gas-related $\mathrm{CH}_{4}$ emissions in 2017 were estimated to be around 80 Mton. Specific $\mathrm{CH}_{4}$ emissions from diesel and fuel oil are generally much higher than coal and natural gas according to Figure 12b. A substantial fraction of this is again due to the systemic leakage at the petrochemical facilities [110], and the mismatch in energy input and electricity generation data aforementioned. Fortunately, diesel and fuel oil are no longer the primary energy mix in any ASEAN countries.

\subsection{Nitrous Oxide, $\mathrm{N}_{2} \mathrm{O}$ Emission}

Similar to $\mathrm{CH}_{4}$, the $\mathrm{N}_{2} \mathrm{O}$ emission is minor compared to the $\mathrm{CO}_{2}$ emission, but it is far more potent than $\mathrm{CO}_{2}$ and may lead to ozone depletion as well. The majority of the world $\mathrm{N}_{2} \mathrm{O}$ emission is from agricultural soil management (74\%) and secondly from stationary combustion (8\%), particularly from the power plants [111]. $\mathrm{N}_{2} \mathrm{O}$ emission is a by-product of fuel combustion, arising from oxidation of fuel nitrogen [112]. Since coal contains a higher content of nitrogen, the highest concentrations of $\mathrm{N}_{2} \mathrm{O}$ are observed in coal flames and the lowest levels in the natural gas flame [113].

Therefore, it is no surprise that more than $80 \%$ of the annual $\mathrm{N}_{2} \mathrm{O}$ emission in the Malaysia electricity sector is from coal power plants since 2003, two years after coal became the primary energy source. This is shown in Figure 13a. In comparison, the $\mathrm{N}_{2} \mathrm{O}$ emission from natural gas, diesel and fuel oil is relatively negligible. The specific $\mathrm{N}_{2} \mathrm{O}$ emission in Figure 13b, after accounting for the plant conversion efficiency, also shows that coal is consistently having nearly 20 times more specific $\mathrm{N}_{2} \mathrm{O}$ emission than natural gas. The diesel and fuel oil data are again influenced by the inconsistency in data available and hence not the interest of discussion here.

Other factors that contributed to the high specific $\mathrm{N}_{2} \mathrm{O}$ emission from coal power plant are the technology and combustion features, lack of pollution control equipment, and the surrounding environment [114]. Temperature optimization alone is insufficient in controlling the $\mathrm{N}_{2} \mathrm{O}$ emission in the combustion process. Instead, gas afterburning and solid-catalysed $\mathrm{N}_{2} \mathrm{O}$ decomposition are identified as the most promising measures for $\mathrm{N}_{2} \mathrm{O}$ emission abatement [115]. 


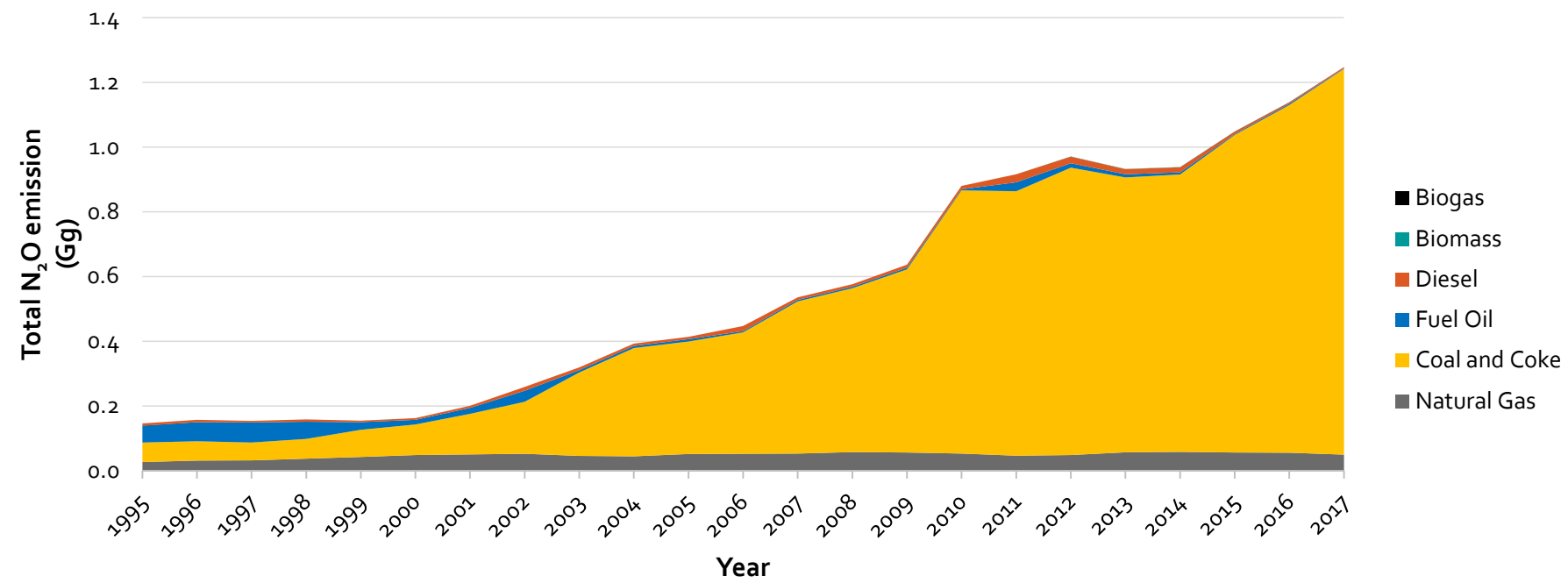

(a)

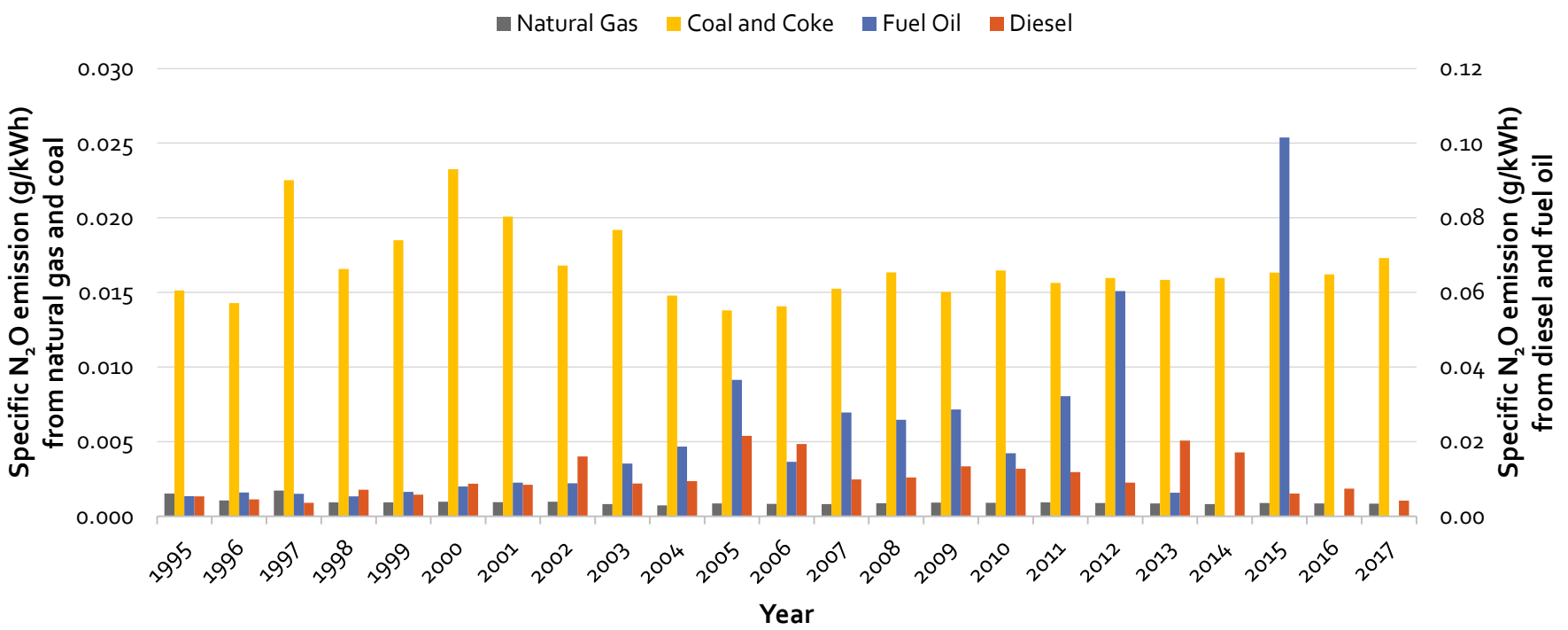

(b)

Figure 13. (a) Total annual and (b) specific $\mathrm{N}_{2} \mathrm{O}$ emissions from Malaysia electricity generation sector from 1995 to 2017.

\subsection{Indirect GHG Emissions}

Besides the direct GHG emissions discussed above, there are a few indirect GHG emissions that are worth discussing. These are the sulphur-dioxide, $\mathrm{SO}_{2}$; nitrogen oxide, $\mathrm{NO}_{\mathrm{x}}$ and carbon monoxide, $\mathrm{CO}$ emission. $\mathrm{SO}_{2}$ emission is produced from the oxidation of sulphur impurities in many fossil fuels during combustion. When dissolved in rainwater droplets, $\mathrm{SO}_{2}$ leads to sulphurous acid or acid rain formation. Heavy fuel oil is identified to emit the highest concentration of $\mathrm{SO}_{2}$ emission, followed by coal then diesel oil, while natural gas is commonly regarded to have negligible sulphur content [116]. The purity level of fuel being used in power plants is not usually known, and may vary from one plant to another, hence making the calculation of $\mathrm{SO}_{2}$ not reliable.

Most $\mathrm{NO}_{\mathrm{x}}$ is known to form through thermal $\mathrm{NO}_{\mathrm{x}}$, resulting from the thermal dissociation and subsequent reaction between nitrogen and oxygen molecules during combustion. The amount of $\mathrm{NO}_{\mathrm{x}}$ emission is highly subjected to the combustion quality, i.e., the oxygen concentration, peak temperature and time of exposure at peak temperature. On the other hand, $\mathrm{CO}$ emission results from incomplete combustion of fossil fuel, subjected to variation of fuel oxidation efficiency and boiler size (high-temperature residence time). The presence of $\mathrm{CO}$ emission in atmosphere will affect the tropospheric (ground layer) ozone and indirectly accelerate the climate change and global warming [117]. 
In short, the emissions of indirect GHGs are subjected to a wide variety of local uncertainties such as the fuel and combustion quality variation from one power plant to another. This may be seen from the emission factor for indirect GHGs provided by [116], where it is further narrowed down to the exact type of fuel, its carbon content, and the combustion chamber/boiler being used and even the configuration of firing. While this will be useful for individual power plants in estimating their indirect GHGs emission, it offers very little help here without knowing the exact specification of each power plant that contributed to the energy data in Figure 4.

Thus, indirect GHG emission calculation will not be attempted here since it could never be as reliable as first-hand emission data. Nevertheless, de Gouw et al. [118] has shown that natural gas power plants in the United States are producing $\sim 40 \%$ less $\mathrm{NO}_{\mathrm{x}}$ and $\mathrm{SO}_{2}$ after switching from coal.

\subsection{Combined Specific GHG Emission}

By combining the energy mix data from Section 3, the combined specific emission of Malaysia electricity generation sector throughout the last two decades could be calculated and given in Figure 14. The combined specific emission represents the associated GHG emission for every kWh of electricity consumed by end users in Malaysia. The major government incentive moves are also included in Figure 14 as a reference.

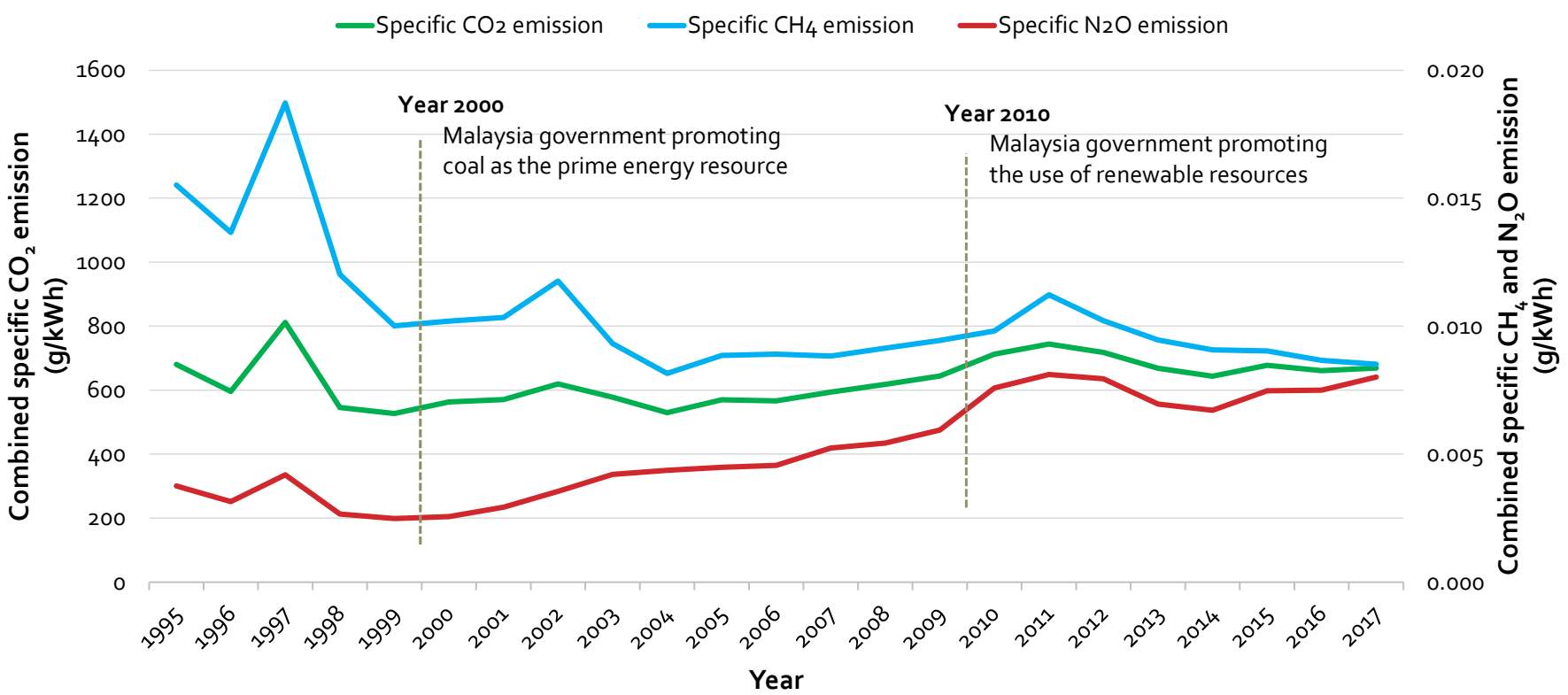

Figure 14. Combined specific emission from Malaysia electricity generation sector from 1995 to 2017.

It is clear that government incentives are the prime mover of the Malaysia specific emission trend. Since the promotion of coal as a primary energy resource in 2000, the specific $\mathrm{N}_{2} \mathrm{O}$ emission has been gradually soaring upward over that decade. Towards the year 2010, the annual combined specific $\mathrm{N}_{2} \mathrm{O}$ emission is close to two times higher than at the beginning of the decade, and this is completely due to the coal power plant expansion.

A similar trend may be observed in the combined specific $\mathrm{CO}_{2}$ emission. The shift from natural gas to coal for coping with the nation's electricity demand leads to a $32 \%$ increase of combined specific $\mathrm{CO}_{2}$ emission in that decade. The raise is less drastic compared to $\mathrm{N}_{2} \mathrm{O}$ as the specific $\mathrm{N}_{2} \mathrm{O}$ emission of coal is nearly 20 times that from natural gas. It is also due to the same government incentive, and the combined specific $\mathrm{CH}_{4}$ emission remained within $10 \%$ in that decade.

In 2010, hydropower accounted for 5\% of the total Malaysia energy mix. Since the numerous renewable energy policies that have been put in place, this number rose to $17 \%$ in the following seven years. In fact, the energy mix data show the expansion of all fossil 
fuel power plants had come to a halt since 2010, and all growing electricity demand was fulfilled mostly via hydropower generation.

The increase of renewable energy resources like hydropower brought a positive trend to the nation's combined specific emission. From 2010 to 2017, the combined $\mathrm{CO}_{2}$ and $\mathrm{CH}_{4}$ emissions dropped by $6 \%$ and $13 \%$, respectively. Although the combined $\mathrm{N}_{2} \mathrm{O}$ emission did not reduce like the other two GHGs, its gradual annual increment was radically decreased to $6 \%$ in that 7 -year time period.

\section{Discussion and Limitations}

Malaysia is recognised as one of the fastest-growing GHG emissions countries in the world, with a compounded annual growth rate (CAGR) of 7.9\% from 1990 to 2006 [28]. In order to replace the conventional fossil fuel as the primary energy mix, it is estimated that renewable generation needs to expand at the current rate for another two decades. However, Figure 9 indicates that $80 \%$ of the next 5-year plan for Malaysia power generation capacity expansion is still made up of natural gas combustion. Furthermore, it is impossible to completely discard the annual $120 \mathrm{TJ}$ of generation from natural gas and coal. Thus, fossil fuel is still anticipated to be the primary energy mix in the coming decade.

The global natural gas demand is projected to rise at an annual rate of $18 \%$ until 2035, and the electricity sector is anticipated to be the primary end-use sector in driving the demand [119]. Many countries are continuously looking at ways to allow better use of natural gas as an alternative energy source to further reduce its carbon emissions [120]. Many of these are focused on the improvement of plant conversion efficiency. Likewise, the relatively low efficiency of many coal power plants in Malaysia will significantly increase the adverse effects on GHG emissions [92]. Coal power plant efficiency may be enhanced via the ultra-supercritical technology and clean coal technology such as the one utilised in the Manjung 4 Power Plant [121]. The Manjung 4 coal power plant is delivering $42 \%$ of daily conversion efficiency, compared to the global average of 33\% [92,122].

Waste heat energy recovery (WHR) technology has also been gaining attention since the last decade as an effort to reduce the GHG emissions with fossil fuel generation [123-125]. Conventional WHR technology is expected to elevate the plant efficiency by some $4 \%$, and studies have been ongoing to increase this number to close to $8 \%$ by compounding various WHR technologies [126,127]. However, most of these technologies are still in their early phase and could use some push from the government's incentive to propel them.

There is still a long way to go for Malaysia to transform into a fully renewable energy mix. The major challenge of implementing new renewable energies always lies in their economical feasibility. Higher initial cost and a much longer payback period inevitably hindered the attractiveness of new technologies and their market penetration. On top of that, the technical factor in terms of the suitability of technology and availability of local expertise in these technologies is another difficulty to overcome [128].

Carbon neutral status can be achieved in two ways, i.e., carbon mitigation and carbon removal. The conventional carbon mitigation techniques are to phase out the fossil fuel power plant and replace it with the clean and renewable power source. Whereas carbon removal techniques rely on natural or artificial sinks to capture and remove the carbon in the air, during the transition to achieve net-zero emissions, before all combustion power plants are obsoleted, the use of alternative (carbon-neutral) fuel is foreseen to take off as the substitution of conventional fossil fuel [129-131].

Another energy-consuming sector that should not be overlooked is the transportation sector that contributed $16 \%$ to the global $\mathrm{CO}_{2}$ emission (Figure 1). To date, the Malaysia transportation sector is almost exclusively relying on fossil fuel combustion. The global promotion of electric vehicles in recent years will further increase the electricity demand on top of the nation's economic growth. Therefore, a decision should be made by taking the specific GHG emission of the nation's energy mix into consideration. This topic alone deserves a dedicated discussion and hence will not be covered in this study. 
Even though the present study places emphasis on the electricity sector in Malaysia, the implication on energy policy, from the finding of this study, is generally applicable to countries with a similar energy mix. This is particularly true for the Asian countries that are still heavily relying on fossil fuels to cope with the surge in electricity demand caused by the rising industrial sector. The choice of renewable energy, however, is more often subjected to geopolitical influence and varies from country to country. Nonetheless, similar underlying difficulties owned by each energy source, as discussed in this paper, are commonly found in many developing countries.

\section{Conclusions and Recommendations}

In summary, this paper presented the energy mix for electricity generation in Malaysia from 1995 to 2017 and the corresponding evolution in GHG emissions. To date, Malaysia's power generation is still dominated by the two major sources of fossil fuels, which is natural gas and coal, leaving renewable resources to play catch up. The government's incentive proved to be the prime mover of the energy mix, more than any other factors. On average, it took a decade for a significant reduction in specific GHG emission to be visible from the government's energy policy implementation.

Among fossil fuel energy, coal generation is the largest contributor to $\mathrm{CO}_{2}$ and $\mathrm{N}_{2} \mathrm{O}$ emissions in the electricity sector. Most $\mathrm{CH}_{4}$ emission is from the systemic leakage during natural gas transport and the coal mining process. However, for renewable energy, the share of hydropower in Malaysia's electricity generation mix is expected to expand continuously. The ever-cheaper solar panel module worldwide is making it the next favourable largescale renewable energy option. Together with biogas and biomass, for which their usage is yet to be maximized, these are the four prospect primary renewable resources for the electricity generation mix in Malaysia. The shift in Malaysia government's incentive in the primary resource in the last two decades or so leads to clear changes in the trend of specific GHG emissions. Particularly, the renewable energy policies implemented at the end of the last decade has successfully lowered the combined specific $\mathrm{CO}_{2}$ and $\mathrm{CH}_{4}$ emissions and suppressed the increment of specific $\mathrm{N}_{2} \mathrm{O}$ emission.

To this end, the next incentive of Malaysia government will be paramount, as evidenced in the past two decades. Therefore, two implications for future energy policy may be summarised from the current study. Firstly, resource diversification of energy security was the main driving force of past energy policies in Malaysia. Moving forward, the factor of GHG emissions must also be included in the equation, though the often-unseen environmental complication from renewable energy must not be neglected. Secondly, the complete substitution of fossil fuel in energy mix is not imminent; hence, the contribution of other zero-emission renewable energy resources, improvement in conventional carbon mitigation techniques, and upcoming carbon removal techniques will be vital in cutting down the specific GHG emissions from Malaysia's electricity generation sector towards achieving a net-zero carbon nation.

The current study focused only on the electricity sector-the largest source of $\mathrm{CO}_{2}$ emissions. For a complete GHG emissions scenario in Malaysia, the future study shall look into the transportation, agricultural and industrial processes in Malaysia. This would not only benefit the policymakers, but also the end-users in understanding the carbon footprint associated with their activities.

Author Contributions: Methodology, formal analysis, investigation, data curation, S.N.A.L. and A.T.; writing-original draft preparation, S.N.A.L.; writing—review and editing, M.S.C., A.T. and S.R.; supervision, M.S.C., Y.-Y.C. and K.T.; funding acquisition, M.S.C., Y.-Y.C. and Y.I. All authors have read and agreed to the published version of the manuscript.

Funding: This research was funded by the Japan Science \& Technology Agency (JST) and Japan International Cooperation Agency (JICA), and the Ministry of Higher Education Malaysia (MoHE) registered program cost centre: \#R.J130000.7851. 4L893. The APC was funded by the National Institute of Advanced Industrial Science and Technology (AIST). 
Institutional Review Board Statement: Not applicable.

Informed Consent Statement: Not applicable.

Data Availability Statement: The data are publicly available and may be obtained from the cited references.

Acknowledgments: This work was supported by the Science and Technology Research Partnership for Sustainable Development (SATREPS) Program entitled 'Development of Advanced Hybrid Ocean Thermal Energy Conversion (OTEC) Technology for Low Carbon Society and Sustainable Energy System: First Experimental OTEC Plant of Malaysia' funded by Japan Science \& Technology Agency (JST) and Japan International Cooperation Agency (JICA), and Ministry of Higher Education Malaysia (MoHE).

Conflicts of Interest: The authors declare no conflict of interest.

\section{References}

1. BP. Statistical Review of World Energy; 2013. Available online: http://large.stanford.edu/courses/2013/ph240/lim1/docs/ bpreview.pdf (accessed on 14 April 2021).

2. Ellabban, O.; Abu-Rub, H.; Blaabjerg, F. Renewable energy resources: Current status, future prospects and their enabling technology. Renew. Sustain. Energy Rev. 2014, 39, 748-764. [CrossRef]

3. IEA. Electricity Information Overview; Technical Report; IEA: Paris, France, 2019.

4. World Meteorological Organization. Statement by WMO Secretary-General Petteri Taalas. 2019. Available online: https: / / public.wmo.int/en/media/news/statement-wmo-secretary-general-petteri-taalas (accessed on 1 June 2020).

5. Masson-Delmotte, V.; Zhai, P.; Pörtner, H.O.; Roberts, D.; Skea, J.; Shukla, P.R.; Pirani, A.; Moufouma-Okia, W.; Péan, C.; Pidcock, R.; et al. IPCC, 2018: Global Warming of $1.5^{\circ} \mathrm{C}$. an IPCC Special Report on the Impacts of Global Warming of $1.5^{\circ} \mathrm{C}$ above PreIndustrial Levels and Related Global Greenhouse Gas Emission Pathways, in the Context of Strengthening the Global Response to the Threat of Climate Change, Sustainable Development, and Efforts to Eradicate Poverty; Technical Report; IPCC: Geneva, Switzerland, 2018.

6. EPA. Overview of Greenhouse Gases. 2020. Available online: https://www.epa.gov/ghgemissions/overview-greenhouse-gases (accessed on 1 June 2020).

7. Demirbas, A. Carbon dioxide emissions and carbonation sensors. Energy Sources Part A Recover. Util. Environ. Eff. 2008, 30, 70-78. [CrossRef]

8. Abdallah, L.; El-Shennawy, T. Reducing carbon dioxide emissions from electricity sector using smart electric grid applications. J. Eng. 2013, 2013, 845051. [CrossRef]

9. Moazzem, S.; Rasul, M.; Khan, M.M.K. A Review on Technologies for Reducing $\mathrm{CO}_{2}$ Emission From Coal Fired Power Plants; InTech: London, UK, 2012; Chapter 11, pp. 227-254.

10. Krivolapchuk, I.A. Energy-supply of the muscular activity at boys of 13-14 years in dependence from rates of puberty. Fiziol Cheloveka 2011, 37, 85-96.

11. Smith, M.S.; Cook, C.; Sokona, Y.; Elmqvist, T.; Fukushi, K.; Broadgate, W.; Jarzebski, M.P. Advancing sustainability science for the SDGs. Sustain. Sci. 2018, 13, 1438-1487. [CrossRef]

12. Fonseca, L.M.; Domingues, J.P.; Dima, A.M. Mapping the sustainable development goals relationships. Sustainability 2020, 12, 3359. [CrossRef]

13. Zimon, D.; Tyan, J.; Sroufe, R. Drivers of sustainable supply chain management: Practices to alignment with unsustainable development goals. Int. J. Qual. Res. 2020, 14. [CrossRef]

14. Fonseca, L.M.; Domingues, J.P.; Pereira, M.T.; Martins, F.F.; Zimon, D. Assessment of circular economy within Portuguese organizations. Sustainability 2018, 10, 2521. [CrossRef]

15. C2ES. Getting to Zero: A U.S. Climate Agenda. Executive Summary. 2019. Available online: https://www.c2es.org/site/assets/ uploads/2019/11/getting-to-zero-a-us-climate-agenda-11-13-19.pdf (accessed on 11 November 2020).

16. Dooley, B.; Inoue, M.; Hida, H. Japan's New Leader Sets Ambitious Goal of Carbon Neutrality by 2050. 2020. Available online: https:/ / www-nytimes-com.cdn.ampproject.org/c/s/www.nytimes.com/2020/10/26/business/japan-carbon-neutral. amp.html (accessed on 11 November 2020).

17. Sengupta, S. China, in Pointed Message to U.S., Tightens Its Climate Targets. 2020. Available online: https://www.nytimes.com/ 2020/09/22/climate/china-emissions.html (accessed on 11 November 2020).

18. Mohamed, A.R.; Lee, K.T. Energy for sustainable development in Malaysia: Energy policy and alternative energy. Energy Policy 2006, 34, 2388-2397. [CrossRef]

19. Jamaludin, A.F.B. Energy mix and alternatives energy for sustainable development in Malaysia. In Proceedings of the The 9th International Students Summit on Food, Agriculture and Environment in the New Century, Tokyo, Japan, 8-9 October 2009.

20. Ong, H.C.; Mahlia, T.M.I.; Masjuki, H.H. A review on energy scenario and sustainable energy in Malaysia. Renew. Sustain. Energy Rev. 2011, 15, 639-647. [CrossRef]

21. Sahid, E.J.M.; Siang, C.C.; Peng, L.Y. Enhancing energy security in Malayia: The challenges towards sustainable environment. IOP Conf. Ser. Earth Environ. Sci. 2013, 16. [CrossRef] 
22. Ali, R.; Daut, I.; Taib, S. A review on existing and future energy sources for electrical power generation in Malaysia. Renew. Sustain. Energy Rev. 2012, 16, 4047-4055. [CrossRef]

23. Samsudin, M.S.N.; Rahman, M.M.; Wahid, M.A. Power generation sources in Malaysia: Status and prospects for sustainable development. J. Adv. Rev. Sci. Res. 2016, 25, 11-28.

24. VGB Powertech. Electricity Generation 2019|2020. 2019. Available online: https://www.vgb.org/en/data_powergeneration. html?dfid=98054 (accessed on 11 April 2021).

25. C2ES. Global Emissions. Energy/Emissions Data. 2020. Available online: https://www.c2es.org/content/internationalemissions / (accessed on 11 November 2020).

26. Ritchie, H.; Roser, M. Emissions by Sector. 2020. Available online: .https:/ / ourworldindata.org/emissions-by-sector (accessed on 30 November 2020).

27. EIA. Global Natural Gas Markets Overview: A Report Prepared by Leidos, Inc., under Contract to EIA. Working Paper Series. 2014. Available online: https://www.eia.gov/workingpapers/pdf/global_gas.pdf (accessed on 10 April 2021).

28. Sandu, S.; Yang, M.; Mahlia, T.M.I.; Wongsapai, W.; Ong, H.C.; Putra, N.; Rahman, S.M.A. Energy-related $\mathrm{CO}_{2}$ emissions growth in ASEAN countries: Trends, drivers and policy implications. Energies 2019, 12, 4650. [CrossRef]

29. Beeson, M. Contemporary Southeast Asia: Regional Dynamics, National Differences; Palgrave Macmillan: Basingstoke, UK, 2009.

30. ASEAN Centerfor Energy; Deutsche Gesellschaft fr Internationale Zusammenarbeit GmbH. The 5th ASEAN Energy Outlook. 2017. Available online: https:/ / aseanenergy.org/the-5th-asean-energy-outlook/ (accessed on 11 April 2021).

31. Silitonga, A.S.; Mahlia, T.M.I.; Ong, H.C.; Riayatsyah, T.M.I.; Kusumo, F.; Ibrahim, H.; Dharma, S.; Gumilang, D. A comparative study of biodiesel production methods for Reutealis trisperma biodiesel. Energy Sources Part A Recover. Util. Environ. Eff. 2017, 39, 2006-2014. [CrossRef]

32. Mofijur, M.; Mahlia, T.M.I.; Silitonga, A.S.; Ong, H.C.; Silakhori, M.; Hasan, M.H.; Putra, N.; Rahman, S.M.A. Phase Change Materials (PCM) for solar energy usages and storage: An overview. Energies 2019, 12, 3167. [CrossRef]

33. Ong, H.C.; Masjuki, H.H.; Mahlia, T.M.I.; Silitonga, A.S.; Chong, W.T.; Yusaf, T. Engine performance and emissions using Jatropha curcas, Ceiba pentandra and Calophyllum inophyllum biodiesel in a CI diesel engine. Energy 2014, 69, 427-445. [CrossRef]

34. Silitonga, A.S.; Masjuki, H.H.; Mahlia, T.M.I.; Ong, H.C.; Chong, W.T. Experimental study on performance and exhaust emissions of a diesel engine fuelled with Ceiba pentandra biodiesel blends. Energy Convers. Manag. 2013, 76, 828-836. [CrossRef]

35. Silitonga, A.S.; Masjuki, H.H.; Ong, H.C.; Sebayang, A.H.; Dharma, S.; Kusumo, F.; Siswantoro, J.; Milano, J.; Daud, K.; Mahlia, T.M.I.; et al. Evaluation of the engine performance and exhaust emissions of biodiesel-bioethanol-diesel blends using kernel-based extreme learning machine. Energy 2018, 159, 1075-1087. [CrossRef]

36. IEA. Southeast Asia Energy Outlook 2019; Technical Report; IEA: Paris, France, 2019.

37. Energy Commission. National Energy Balance 2017. 2017. Available online: https://meih.st.gov.my/documents/10620/f85ba3 ae-fd44-4ea4-a69d-400c5f96b3ea (accessed on 1 June 2020).

38. Kumar, S.; Abdul Salam, P.; Shrestha, P.; Ackom, E.K. An assessment of thailand's biofuel development. Sustainability 2013, 5, 1577-1597. [CrossRef]

39. Chong, C.; Ni, W.; Ma, L.; Liu, P.; Li, Z. The use of energy in Malaysia: Tracing energy flows from primary source to end use. Energies 2015, 8, 2828-2866. [CrossRef]

40. Anwar, A.; Taib, S.; Mujeebu, M.A.; Salah, W.A. Analysis of sectoral energy conservation in Malaysia. Energy 2009, 34, 733-739.

41. European Commission. ILCD Handbook: General Guidefor Life Cycle Assessment_Detailed Guidance; Technical Report; Joint Research Centre, Institute for Environment and Sustainability: Luxembourg, 2010. [CrossRef]

42. Corbetta, P. Social Research: Theory, Methods and Techniques; SAGE Publications: Southend Oaks, CA, USA, 2003.

43. Energy Commission. Malaysia Energy Information Hub. 2011. Available online: https://meih.st.gov.my/statistics (accessed on 1 June 2020).

44. Oh, T.H.; Hasanuzzaman, M.; Selvaraj, J.; Teo, S.C.; Chua, S.C. Energy policy and alternative energy in Malaysia: Issues and challenges for sustainable growth-An update. Renew. Sustain. Energy Rev. 2018, 81, 3021-3031. [CrossRef]

45. Khor, C.S.; Lalchand, G. A review on sustainable power generation in Malaysia to 2030: Historical perspective, current assessment, and future strategies. Renew. Sustain. Energy Rev. 2014, 29, 952-960. [CrossRef]

46. Rahim, K.A.; Liwan, A. Oil and gas trends and implications in Malaysia. Energy Policy 2012, 50, 262-271. [CrossRef]

47. MOSTI. Intended Nationally Determined Contribution of the Government of Malaysia. 2019. Available online: https: / / www.mosti.gov.my/web/wp-content/uploads/2019/04/18.Malaysia-Intended-Nationally-Determined-Contributions-toUNFCCC.pdf (accessed on 1 June 2020).

48. Wong, T.S. Renewable Energy Policy in Malaysia. Presentation Slide. 2015. Available online: https://www.google.com/url?sa= t\&rct=j\&q=\&esrc=s\&source=web\&cd=\&ved=2ahUKEwiQlZ2dyP7vAhVMzzgGHSHBDnUQFjAAegQIBhAD\&url=http $\% 3 A \%$ 2F\%2Foverseas.mofa.go.kr\%2Fmy-ko\%2Fbrd\%2Fm_1929\%2Fdown.do\%3Fbrd_id\%3D1591\%26seq\%3D1240972\%26data_tp\% 3DA\%26file_seq\%3D1\&usg=AOvVaw0WTwGD6P46HSrZbpWr9HMU (accessed on 5 June 2020).

49. Hosseini, S.E.; Wahid, M.A.; Aghili, N. The scenario of greenhouse gases reduction in Malaysia. Renew. Sustain. Energy Rev. 2013, 28, 400-409. [CrossRef]

50. Thaddeus, J. Complementary roles of natural gas and coal in Malaysia. In Proceedings of the Joint 8th APEC Coal Flow Seminar and the 9th APEC Clean Fossil Energy Technical Seminar: coal in sustainable development in the 21st century, Kuala Lumpur, Malaysia, 4-5 March 2020. 
51. Minerals and Geoscience Department Malaysia. Malaysian Minerals Yearbook 2013; Minerals and Geoscience Department Malaysia: Terengganu, Malaysia, 2014.

52. Johnston, R.J.; Blakemore, R.; Bell, R. The Role of Oil and Gas Companies in the Energy Transition. 2020. Available online: https:/ / www.atlanticcouncil.org/wp-content/uploads/2020/07/OGT-final-web-version.pdf (accessed on 14 April 2021).

53. De Oliveira, R.L. Powering the Future: Malaysia's Energy Policy Challenges; Techreport 55; Institute for Democracy and Economic Affairs: Kuala Lumpur, Malaysia, 2018.

54. Baruya, P. Prospects for Coal and Clean Coal Technologies in Malaysia; Techreport CCC/171; IEA Clean Coal Centre: London, UK, 2010.

55. Mushtaq, F.; Maqbool, W.; Mat, R.; Ani, F.N. Fossil fuel energy scenario in Malaysia-prospect of indigenous renewable biomass and coal resources. In Proceedings of the 2013 IEEE Conference on Clean Energy and Technology (CEAT), Langkawi, Malaysia, 18-20 November 2013.

56. EIA. Subbituminous and Bituminous Coal Dominate U.S. Coal Production. 2011. Available online: https://www.eia.gov/ todayinenergy / detail.php?id=2670\# (accessed on 5 June 2020).

57. Weise, E. On World Environment Day, Everything You Know About Energy in the US Might Be Wrong. 2019. Available online: https:/ / www.usatoday.com/story/news/2019/06/04/climate-change-coal-now-more-expensive-than-wind-solar-energy / 1277637001/ (accessed on 31 December 2020).

58. Nikkei Asia. Contracts for $\$ 537$ Million to Secure Long-Term Coal Supply to Malaysia. 2016. Available online: https: / /asia.nikkei.com/Business/Contracts-for-537-million-to-secure-long-term-coal-supply-to-Malaysia (accessed on 31 December 2020).

59. Energy Commission. Peninsular Malaysia Electricity Supply: Outlook 2017. 2017. Available online: https://www.st. gov.my/en/contents / publications/outlook/Peninsular\%20Malaysia\%20Electricity\%20Supply\%20Outlook\%202017.pdf\#: : text=In \%20the \%202017\%20Federal\%20budget, \%25\%20to\%205.0\%25\%20in \%202017.\&text=Therefore \%2C \%20electricity \%20 sales $\% 20$ is \%20projected, \%25\%20to\%202.5\%25\%20in\%202017. (accessed on 11 November 2020).

60. Shamsuddin, A.H. Development of renewable energy in Malaysia-Strategic initiatives for carbon reduction in the power generation sector. Procedia Eng. 2012, 49, 384-391. [CrossRef]

61. Kailasam, K. Community Water Quality Monitoring Programme in Malaysia; Technical Report; International Forum on Water Environmental Governance in Asia; Global Environment Centre: Petaling Jaya, Malaysia, 2007.

62. Scott, J.C. Seeing Like a State: How Certain Schemes to Improve the Human Condition Have Failed; Yale University Press: London, UK, 1999.

63. Crețan, R.; Vesalon, L. The political economy of hydropower in the communist space: Iron Gates revisited. Tijdschr. Voor Econ. Soc. Geogr. 2017, 108, 688-701. [CrossRef]

64. Swyngedouw, E. Technonatural revolutions: The scalar politics of Franco's hydro-social dream for Spain, 1939-1975. Trans. Inst. Br. Geogr. 2007, 32, 9-28. [CrossRef]

65. Wahby, W. The Three Gorges Dam of China: Technology to bridge two centuries. J. Technol. Stud. 2003, 29, 19-25. [CrossRef]

66. Li, K.; Zhu, C.; Wu, L.; Huang, L. Problems caused by the Three Gorges Dam construction in the Yangtze river basin: A review. Environ. Rev. 2013, 21, 127-135. [CrossRef]

67. Mekhilef, S.; Saidur, R.; Safari, A.; Mustaffa, W.E.S.B. Biomass energy in Malaysia: Current state and prospects. Renew. Sustain. Energy Rev. 2011, 15, 3360-3370. [CrossRef]

68. Goh, C.S.; Tan, K.T.; Lee, K.T.; Bhatia, S. Bio-ethanol from lignocellulose: Status, perspectives and challenges in Malaysia. Bioresour. Technol. 2010, 101, 4834-4841. [CrossRef]

69. National Geographic. Biomass Energy. 2012. Available online: https://www.nationalgeographic.org/encyclopedia/biomassenergy /\#: :text=Biomass \%20energy\%20is\%20energy\%20generated,heat\%20or\%20converted\%20into\%20electricity (accessed 31 December 2020).

70. Hanafiah, M.M. Biogas production from different substrates under anaerobic conditions. In Proceedings of the 3rd lnternational Conference on Chemical, Agricultural and Medical Sciences (CAMS-2015), Singapore, 10-11 December 2015.

71. Tan, Z.Y. Green Technology: Time to Tap Biomass. 2020. Available online: https://www.theedgemarkets.com/article/greentechnology-time-tap-biomass (accessed 31 December 2020).

72. Seljak, T.; Pavalec, K.; Buffi, M.; Valera-Medina, A. Challenges and solutions for utilization of bioliquids in microturbines. J. Eng. Gas Turbines Power 2018, 141, 031401. [CrossRef]

73. Cheng, S.; Li, Z.; Mang, H.; Neupane, K.; Wauthelet, M.; Huba, E. Application of fault tree approach for technical assessment of small-sized biogas systems in Nepal. Appl. Energy 2014, 113, 1372-1381. [CrossRef]

74. Chang, I.; Zhao, J.; Yin, X.; Wu, J.; Jia, Z.; Wang, L. Comprehensive utilizations of biogas in Inner Mongolia, China. Renew. Sustain. Energy Rev. 2011, 15, 1442-1453. [CrossRef]

75. Hamid, M.R.; Haque, M.N.; Rouf, M.A.; Islam, M.S. Dissemination of domestic biogas plants in Bangladesh-Current state, problems faced and barriers. Int. J. Sci. Eng. Res. 2013, 4, 45000.

76. Roubk, H.; Mazancov, J.; Banout, J.; Verner, V. Addressing problems at small-scale biogas plants: A case study from central Vietnam. J. Clean. Prod. 2016, 112, 2784-2792. [CrossRef]

77. Hall, D.O.; Rosillo-Calle, F.; de Groot, P. Biomass energy: Lessons from case studies in developing countries. Energy Policy 1992, 20, 62-73. [CrossRef] 
78. Mekhilef, S.; Safari, A.; Mustaffa, W.E.S.; Saidur, R.; Omar, R.; Younis, M.A.A. Solar energy in Malaysia: Current state and prospects. Renew. Sustain. Energy Rev. 2012, 16, 386-396. [CrossRef]

79. Naam, R. Solar's Future Is Insanely Cheap. 2020. Available online: https://rameznaam.com/2020/05/14/solars-future-isinsanely-cheap-2020/ (accessed 31 December 2020).

80. Niranjan, A. Falling Solar Panel Prices Spell Sunny Future for Clean Energy. 2020. Available online: https://www.dw.com/en/ cheap-solar-energy-prices-explained/a-53590607 (accessed 31 December 2020).

81. Panos, K. The Dark Side of Solar Power. 2020. Available online: https://hackaday.com/2020/12/02/the-dark-side-of-solarpower/ (accessed 31 December 2020).

82. Gomesh, N.; Daut, I.; Irwanto, M.; Irwan, Y.M.; Fitra, M. Study on Malaysian's perspective towards renewable energy mainly on solar energy. Energy Procedia 2013, 36, 303-312. [CrossRef]

83. Solar Panel Malaysia. An Overview of the Feed-In Tariff in Malaysia. 2019. Available online: https://www.solarpanelmalaysia. $\mathrm{com} /$ fit/an-overview-of-the-feed-in-tariff-in-malaysia/ (accessed on 5 June 2020).

84. Barrock, J. Response to 1400 mw Solar Jobs Could Be Lukewarm. 2020. Available online: https://www.theedgemarkets.com/ article/response-1400mw-solar-jobs-could-be-lukewarm (accessed on 31 December 2020).

85. Good, C.S.; Lobaccaro, G.; Hårklau, S. Optimization of solar energy potential for buildings in urban areas-A Norwegian case study. Energy Procedia 2014, 58, 166-171. [CrossRef]

86. Zhang, J.; Xu, L.; Shabunko, V.; Tay, S.E.R.; Sun, H.; Lau, S.S.Y.; Reindl, T. Impact of urban block typology on building solar potential and energy use efficiency in tropical high-density city. Appl. Energy 2019, 240, 513-533. [CrossRef]

87. Sarralde, J.J.; Quinn, D.J.; Wiesmann, D.; Steemers, K. Solar energy and urban morphology: Scenarios for increasing the renewable energy potential of neighbourhoods in London. Renew. Energy 2015, 73, 10-17. [CrossRef]

88. Amado, M.; Poggi, F. Solar urban planning: A parametric approach. Energy Procedia 2014, 48, 1539-1548. [CrossRef]

89. Lin, A.; Lu, M.; Sun, P. The influence of local environmental, economic and social variables on the spatial distribution of photovoltaic applications across China's urban areas. Energies 2018, 11, 1986. [CrossRef]

90. Lundgren, M.; Dahlberg, J. Approaches, methods and tools for solar energy in urban planning. Report. 2018. Available online: http:/ task51.iea-shc.org/Data/Sites/1/publications/Task51_ReportB2_180815.pdf (accessed on 11 April 2021).

91. Kanters, J.; Wall, M.; Dubois, M. Typical values for active solar energy in urban planning. Energy Procedia 2014, 48, 1607-1616. [CrossRef]

92. Babatunde, K.A.; Said, F.F.; Nor, N.G.M. Reducing carbon dioxide emissions from Malaysian power sector: Current issues and future directions. J. Kejuruter. SI 2018, 1, 59-69.

93. Wasiu, O.I.; Alasinrin, B.K. Growth thresholds and environmental degradation in sub-Saharan African countries: An exploration of kuznets hypothesis. Int. J. Manag. Account. Econ. 2015, 2, 858-871.

94. IPCC. Stationary Combustion: Sectoral Approach. 2006. Available online: https://www.ipcc-nggip.iges.or.jp/public/2006gl/ pdf/2_Volume2/V2_2_Ch2_Stationary_Combustion.pdf (accessed on 5 June 2020).

95. MESTECC. Malaysia Third National Communication and Second Biennial Update Report to the UNFCCC. Technical Report; Ministry of Energy, Science, Technology, Environment and Climate Change: Putrajaya, Malaysia, 2018.

96. Huda, M.; Okajima, K.; Suzuki, K. $\mathrm{CO}_{2}$ emission from electricity generation in Malaysia: A decomposition analysis. J. Energy Power Eng. 2017, 11, 779-788.

97. Martunus.; Othman, M.R.; Zakaria, R.; Fernando, W.J.N. $\mathrm{CO}_{2}$ emission and carbon capture for coal fired power plants in Malaysia and Indonesia. In Proceedings of the International Conference on Environment 2008 (ICENV 2008), Penang, Malaysia, 15-17 December 2008.

98. IndexMundi. Commodity Prices. 2020. Available online: https:/ /www.indexmundi.com/commodities/ (accessed on 7 June 2020).

99. Zhang, X.; Yu, L.; Wang, S. The impact of financial crisis of 2007-2008 on crude oil price. In Proceedings of the International Conference on Computational Science, Baton Rouge, LA, USA, 25-27 May 2009; pp. 643-652.

100. DiChristopher, T. The Financial Crisis Crushed Record Oil Prices but the Market Is Still Gripped by Boom and Bust. 2012 Available online: https:/ /www.cnbc.com/2018/09/12/financial-crisis-crushed-record-oil-prices-but-another-boom-looms.html (accessed on 7 June 2020).

101. EIA. Natural Gas Prices Drop Following Strong Production Growth. 2015. Available online: https://www.eia.gov/ todayinenergy / detail.php?id=19751 (accessed on 7 June 2020).

102. Farrington, S. Diesel Prices Hit Five-Year Low. 2015. Available online: https://www.bbc.com/news/business-33920826 (accessed on 14 April 2021).

103. Heilig, G.K. The greenhouse gas methane $\left(\mathrm{CH}_{4}\right)$ : Sources and sinks, the impact of population growth, possible interventions. Popul. Environ. A J. Interdiscip. Stud. 1994, 16, 109-137. [CrossRef]

104. Wigley, T.M.L. Coal to gas: The influence of methane leakage. Clim. Chang. 2011, 108, 601-608. [CrossRef]

105. Shindell, D.T.; Faluvegi, G.; Koch, D.M.; Schmidt, G.A.; Unger, N.; Bauer, S.E. Improved attribution of climate forcing to emissions. Science 2009, 326, 716-718. [CrossRef]

106. Spath, P.L.; Mann, M.K.; Kerr, D.R. Life Cycle Assessment of Coal-Fired Power Production; Techreport; National Renewable Energy Laboratory: Jefferson County, CO, USA, 1999. 
107. Lavoie, T.N.; Shepson, P.B.; Gore, C.A.; Kaeser, B.H.S.; Wulle, B.; Lyon, D.; Rudek, J. Assessing the methane emissions from natural gas-fired power plants and oil refineries. Environ. Sci. Technol. 2017, 51, 3373-3381. [CrossRef]

108. McGlade, C.; Michaels, K.C.; Gould, T. Global Methane Emissions From Oil and Gas. 2020. Available online: https://www.iea. org/articles/global-methane-emissions-from-oil-and-gas\# (accessed on 1 June 2020).

109. EIA. Emissions of Greenhouse Gases in the United States 2009; Techreport; Energy Information Administration, U.S. Department of Energy: Washington, DC, USA, 2011.

110. Waxman, A.R.; Khomaini, A.; Leibowicz, B.D.; Olmstead, S.M. Emissions in the stream: Estimating the greenhouse gas impacts of an oil and gas boom. Environ. Res. Lett. 2020, 15, 1-12. [CrossRef]

111. Shankman, S. What Is Nitrous Oxide and Why Is It a Climate Threat? 2019. Available online: https://insideclimatenews.org/ news /11092019/nitrous-oxide-climate-pollutant-explainer-greenhouse-gas-agriculture-livestock (accessed on 1 June 2020).

112. Hao, W.M.; Wofsy, S.C.; McElroy, M.B.; Farmayan, W.F.; Togan, M.A.; Beér, J.M.; Zahniser, M.S.; Silver, J.A.; Kolb, C.E. Nitrous oxide concentrations in coal, oil, and gas furnace flames. Combust. Sci. Technol. 1987, 55, 23-32. [CrossRef]

113. EPA. Nitrogen Oxides $\left(\mathrm{NO}_{x}\right)$, Why and How They Are Controlled; Techreport; United States Environmental Protection Agency Clean Air Technology Center: Washington, DC, USA, 1999.

114. EPA. Greenhouse Gas Inventory Guidance: Direct Emissions From Stationary Combustion Sources; Technical Report; United States Environmental Protection Agency Center for Corporate Climate Leadership: Washington, DC, USA, 2016.

115. Wójtowicz, M.A.; Pels, J.R.; Moulijn, J.A. $\mathrm{N}_{2} \mathrm{O}$ emission control in coal combustion. Fuel 1994, 73, 1416-1422. [CrossRef]

116. IPCC. Special Report: Global Warming of $1.5^{\circ}$ C. 2018. Available online: https://www.ipcc.ch/sr15/ (accessed on 11 November 2020).

117. Shindell, D. Understanding Carbon Monoxide as Pollutant and as Agent of Climate Change. 2007. Available online: https: //www.giss.nasa.gov/research/briefs/shindell_09/(accessed on 1 June 2020).

118. De Gouw, J.A.; Parrish, D.D.; Frost, G.J.; Trainer, M. Reduced emissions of $\mathrm{CO}_{2}, \mathrm{NO}_{\mathrm{x}}$, and $\mathrm{SO}_{2}$ from U.S. power plants owing to switch from coal to natural gas with combined cycle technology. Earth's Future 2014, 2, 75-82. [CrossRef]

119. IEA. Asia Is Set to Support Global Coal Demand for the Next, Five Years. 2019. Available online: https://www.iea.org/news / asia-is-set-to-support-global-coal-demand-for-the-next-five-years (accessed on 9 April 2021).

120. Bekhet, H.A.; Yasmin, T. Rapid economic growth and natural gas consumption nexus: Looking forward from perspective of 11th Malaysian plan. IOP Conf. Ser. Earth Environ. Sci. 2016, 32, 012051. [CrossRef]

121. GE. Manjung 4: Powering Malaysia with Clean Coal Technology. 2017. Available online: https://www.ge.com/news/reports/ manjung-4-powering-malaysia-clean-coal-technology (accessed on 10 April 2021).

122. Shah, S.A. TNB Makes Its Mark With 2nd Cleaner Coal-Fired Power Plant. 2017. Available online: https://www.tnb.com.my/ assets/newsclip/12052017b.pdf (accessed on 10 April 2021).

123. Zhang, C.; Romagnoli, A.; Kim, J.; Mohd Azli, A.A.; Rajoo, S.; Lindsay, A. Implementation of industrial waste heat to power in Southeast Asia: an outlook from the perspective of market potentials, opportunities and success catalysts. Energy Policy 2017, 106, 525-535. [CrossRef]

124. Jouhara, H.; Khordehgah, N.; Almahmoud, S.; Delpech, B.; Chauhan, A.; A.Tassou, S. Waste heat recovery technologies and applications. Therm. Sci. Eng. Prog. 2018, 6, 268-289. [CrossRef]

125. Agathokleous, R.; Bianchi, G.; Panayiotou, G.; Aresti, L.; Argyrou, M.C.; Georgiou, G.S.; Tassou, S.A.; Jouhara, H.; Kalogirou, S.A.; Florides, G.A.; et al. Waste heat recovery in the EU industry and proposed new technologies. Energy Procedia 2019, 161, 489-496. [CrossRef]

126. Jin, Y.; Gao, N.; Zhu, T. Techno-economic analysis on a new conceptual design of waste heat recovery for boiler exhaust flue gas of coal-fired power plants. Energy Convers. Manag. 2019, 200, 112097. [CrossRef]

127. Rajoo, S. Energy Recovery in Petroleum Processing via Integrated High Performance Technology; In Proceedings of the Professionals in Energy Series: SPE Malaysia-Thailand JDA Summit, Putrajaya, Malaysia, 2-3 December 2019; The Society for Professionals in Energy: Putrajaya, Malaysia, 2019.

128. Mustapa, S.I.; Peng, L.Y.; Hashim, A.H. Issues and challenges of renewable energy development: A Malaysian experience. In Proceedings of the PEA-AIT International Conference on Energy and Sustainable Development: Issues and Strategies (ESD 2010), Chiang Mai, Thailand, 2-4 June 2010.

129. Wright, C. GreenD+: Sustainable Diesel Alternatives for the Reduction of Carbon Emissions. 2020. Available online: https: //www.azocleantech.com/article.aspx?ArticleID=1111 (accessed on 11 November 2020).

130. Brown, J. Alternative Fuels: The Future of Zero Emissions Shipping. 2018. Available online: https://www.edfeurope.org/news/ 2018/31/07/alternative-fuels-future-zero-emissions-shipping (accessed on 11 November 2020).

131. Rice, M. Producing Clean Hydrogen with Near-Zero Carbon Emissions Using the Hazer Process. 2016. Available online: https:/ / www.azocleantech.com/article.aspx?ArticleID=611 (accessed on 11 November 2020). 